\title{
Expert Recommendations and the Evolution of European Best Practices for the Treatment of Overindebtedness, 1984-2010
}

\author{
Jason J. Kilborn*
}

\section{Introduction}

We academics commonly attempt to influence legislative policy through analysis and recommendation, but we have good reason to wonder whether our messages are hitting their mark. In the United States, for example, especially in the area of consumer protection, we academics often feel as though we're trapped in a Pink Floyd song: we're only coming through in waves; our lips move, but they can't hear what we're saying, as legislators remain comfortably numb $^{1}$ to our suggestions. In Europe, in contrast, at least in the area that interests me mosttreatment of consumer overindebtedness-legislators seem to be more open and responsive.

A series of European experts have weighed in over the years on the proper way forward for preventing and treating consumer overindebtedness. This paper focuses on the lattertreatment, specifically legislation establishing formal debt adjustment ${ }^{2}$ systems - and the variety of laws adopting (and reforming) such systems that have evolved in Europe from the first, in Denmark in 1984, to the most recent, in Greece in July 2010. It first traces and describes in detail the context and content of the series of recommendations that have emerged over the past twenty years. Then, it identifies the shared core of these recommendations and tracks their correspondence with the evolving contours of European laws on debt adjustment and overindebtedness relief. The most common shared recommendations are broken into conceptual parts, with detailed examples of how national laws have taken action, advertently or inadvertently consistent with the experts' views, especially in cases where the original laws failed to heed potential dangers and were later reformed to address emerging problems. Areas where some national laws still lag behind the experts' suggestions are pointed out, as well.

We can now hold up some national systems as examples of best practices and responding to expert recommendations. For other countries, whose laws do not reflect these principles, we might "hold their feet to the fire" in the pursuit of one of our primary academic duties, bringing to light outlier positions and challenging the makers of lagging legal policy to update their laws to the state of the art. Ultimately, this paper identifies the most (and least) persuasive suggestions in terms of legislative acceptance, identifying the likely contours of future systems and reforms, with a focus on particular trouble spots and areas of continuing disagreement. Like many of the recommendations that it analyzes, this paper is designed to inform and guide future European policy makers as overindebtedness law continues its rapid and dynamic evolution.

\footnotetext{
* Professor of Law, John Marshall Law School (Chicago). This paper was prepared as the inaugural lecture for my investiture to the two-year Van der Grinten Chair (wisselleerstoel) in International \& Comparative Insolvency Law at the Radboud University Nijmegen (The Netherlands). Special thanks to Stephanie Ben-Ishai, Hon. Georg Kodek, Johanna Niemi, Arnoud Noordam, Iain Ramsay, and Udo Reifner for particularly helpful comments earlier drafts.

${ }^{1}$ See Roger Waters \& David Gilmour, Pink Floyd, Comfortably Numb (1979), lyrics online at http://www.lyricsfreak.com/p/pink+floyd/comfortably+numb_20108779.html.

2 This term, "debt adjustment," is used in this paper synonymously with other equivalent phrases often used more or less interchangeably in the literature and in legislation, such as “consumer bankruptcy,” "consumer insolvency,” and "overindebtedness," all of which encompass a formal, legal response to an individual's inability to service his or her debt burden. In some national approaches, this concept excludes sole proprietors and others with primarily business-related debts, but no such exclusion is intended in this paper. In particular, the unique terminological distinction in England between "bankruptcy" for consumers and "insolvency" for businesses is not intended here.
} 


\section{The Recommendations: Sources, Contexts, and Principles}

This introductory section lays the groundwork by introducing and dissecting the most prominent and authoritative commentaries on developing European debt adjustment law. The publication dates of these works stretch over an extended period, between 1993, when the idea of overindebtedness relief was in the earliest stages of development in Europe, to 2007, by which point most of the present laws were either already adopted (and often already reformed) or in the legislative process. Despite the distance in time and experience separating them, all of these sources are fairly united in their recommendations as to the core principles and "best practices" of debt adjustment procedures.

\section{A. Huls et al., Overindebtedness of Consumers in the EC Member States (1993)}

The first major examination of consumer overindebtedness and collection of recommendations for legislative solutions was commissioned by the Directorate General of the Consumer Policy Services of the EC in November 1991. For this groundbreaking study, the EC authorities reached out to the preeminent scholar in this area, Nick Huls, then-director of the Leyden Institute of Law and Public Policy, who coordinated this work with Udo Reifner and other top consumer debt scholars in Europe, including Thierry Bourgoignie, Françoise DomontNaert, Johanna Niemi-Kiesiläinen, Norbert Reich, and a large team of national reporters. ${ }^{3}$ Begun in 1991, this study was conducted before the explosion of activity in European overindebtedness legislation in the mid- to late-1990s and 2000s, so its recommendations are based on the little accumulated experience in the new overindebtedness systems in Denmark, France, and Britain, proposals in a few other countries (Germany, the Netherlands, Belgium), as well as Huls's careful study of the U.S. consumer bankruptcy system for the Dutch Department of Economic Affairs.

In developing its recommendations for legal responses to overindebtedness, the Huls study also took into account the principles enunciated in the British "Cork Report,"4 a watershed study of English insolvency law published in 1982. Several consumer-specific principles extracted from the Cork Report set the stage for Huls's study, beginning with the notion that the time had come to recognize that Europe had developed in large part into a credit-based society that required responsible remedies for the inevitable "accidents" of such a society." Acknowledging that the "basic principle should remain that everyone ought to pay back the debts that he has contracted," 6 Huls notes that already ten years earlier, the Cork Report had called for measures to "protect the debtor and his family from undue demands and harassment by their creditors, and at the same time, to have regard for the rights of the creditor," "establish and encourage professional and independent debt-counseling," "guarantee the public interest which is at issue in case of insolvency," and "lower unproductive costs of ineffective debt-collection."7

\footnotetext{
${ }^{3}$ NiCK Huls ET AL., OVERINDEBTEDNESS OF CONSUMERS IN THE EC MEMBER STATES: FACTS AND SEARCH FOR SOLUTIONS 1, 4-5 (Story Scientia: Diegem 1994); see also Nick Huls, Toward a European Approach to Overindebtedness of Consumers, 16 J. CONS. POL’Y. 215 (1993).

${ }^{4}$ Report of the Insolvency Law Review Committee, Insolvency Law and Practice (1982).

${ }^{5}$ Huls, supra note 3, at 220.

${ }^{6} \mathrm{Id}$. at 223.

${ }^{7}$ Id. at $220-21$.
} 
Huls then sets out to identify the best formulation of such measures to protect debtors while having due regard for the interests of creditors and society. Addressing immediately the counterintuitive notion that undermining the age-old notion of pacta sunt servanda could advance the interests of creditors and society, he points out the reality that creditors do not benefit from wooden application of the theoretical rule entitling them to collect in situations where debtors simply lack the means to meet their obligations. Creditors would, however, benefit from a collective system that offered debtors an incentive to be productive and meet their obligations to the extent possible: relief in the form of a discharge of unpaid debt in exchange for a limited period of "best efforts" payments on those debts. This collective approach also avoids the multiplication of expense in the individual enforcement system, "avert[ing] a disastrous battle of interest among the creditors themselves.” Moreover, Huls points out, society suffers from "insisting that the debtor repays heavy debts indefinitely without much likelihood of realistic yield.” In the final analysis, a relief system achieves a win-win-win situation, Huls argues, as creditors benefit from greater and more even distributions, debtors benefit from a fresh start and renewed incentive for productivity, and society benefits from debtors" "renewed vigor" and avoiding the well-documented social costs of allowing debtors to languish in overindebtedness. $^{8}$

Huls then proceeds to sketch out a model based on the primary goal of offering debtors perspective for a brighter future by means of a discharge of unpaid debt after they had applied their best efforts to paying those debts for a restricted period. First, in Huls's model, debt counselors ${ }^{9}$ should deal with overindebtedness outside the courts as far as possible, and the law should be reformed "in order to facilitate and strengthen voluntarily negotiated debt settlements," with a formal, in-court process providing leverage to encourage out-of-court arrangements. ${ }^{10}$ Eligibility for entry to the process should be broad, avoiding barriers such as minimum debt levels, which exclude the poor, as well as "rigid application of the good faith test," which excludes deserving debtors on the basis of subjective normative judgments about their way of life: "good faith is supposed, bad faith must be proven" to exclude only those who have acted fraudulently. ${ }^{11}$ Another important element of access, "[c]osts should not prevent the consumer seeking the relief that the law offers.",12

The heart of Huls's and all later suggestions is a proposed plan for applying the debtor's "best efforts" to pay off as much debt as possible within a reasonably restricted period, concluding with a discharge of most remaining debt. In addition to applying the value of whatever few non-exempt assets the debtor might have, debtors should turn over all of their earnings net of essential expenditures. So long as the debtor is "doing all he can” to earn a discharge, however, settlement should be available also to those who lack redemption capacity. "Hopeless cases" with no option other than a zero-payment plan should not be rejected, though Huls speculates that "[e]ven the minimum wage or social security benefit contains some margin."13 The maximum term of such plans should not exceed four years, and Huls expresses a preference for three years based on the observations of debt counselors as to debtors' ability to

\footnotetext{
${ }^{8}$ Id. at $221-23$.

${ }^{9}$ On the pivotal role and importance of debt counseling, see id. at 229-232, HuLS ET AL. , supra note 3, at 258-62.

${ }^{10}$ Huls, supra note 3, at 224-25; HuLS ET AL., supra note3, at 246.

${ }^{11}$ HuLS ET AL., supra note 3, at 218, 250.

${ }^{12}$ Huls, supra note 3, at 232.

${ }^{13}$ Id. at 225, 227-28; HULS ET AL., supra note 3, at 255.
} 
withstand extended periods of deprivation. Rather than settling on one clear rule, however, Huls emphasizes that there should be "significant flexibility with respect to the duration of the plan."14 The debtor should be allowed to operate "as independently as possible" during the plan period, without undue restrictions on the debtor's control over his or her household and property. ${ }^{15}$ If changed circumstances affect the promised payment, either positively or negatively, there should be some facility for modification by either debtor or creditors. ${ }^{16}$ Exceptions to the discharge should include alimony/support, criminal fines and liabilities resulting from crime or "gross negligence,” though public debts like taxes and utilities should be remitted. ${ }^{17}$

Huls recommends that this proposal be prepared and presented by debt counselors for approval by all affected creditors. If creditor unanimity cannot be achieved, there should be some mechanism for imposing the plan on minority dissenters if, for example, 75\% of creditors are in favor. Otherwise, the debt counselor should sends this plan to the court for approval and imposition by a judge, with appointment of an administrator or trustee, "most likely the debt counselor," to facilitate implementation of the court-imposed plan. ${ }^{18}$

\section{B. INSOL's Consumer Debt Report (2001)}

The mid- and late-1990s witnessed a proliferation of new national laws creating and modifying systems for treating consumer overindebtedness. Consequently, the second major report on this subject had much more on-the-ground experience and legislative material from which to draw in identifying best practices and formulating recommendations. The International Federation of Insolvency Professionals (INSOL International) generally focuses on business insolvency, but it organized a consumer debt meeting in 1997, which enjoyed unexpected popularity. Expanding over the next few years, the newly formed Consumer Debt Committee collected input from "professionals serving a wide variety of roles in the insolvency system including regulators, judges, practitioners and academics.” On the basis of this input, in 2001 it produced its Consumer Debt Report, explicitly designed "to provide a resource for countries developing or reforming laws and systems that attempt to deal with the problems that face consumer debtors." 19 INSOL's Consumer Debt Report would serve as the foundation of all of the later major recommendations for overindebtedness legislation discussed in this paper.

The report is divided into four "principles," which are in turn unevenly subdivided into a total of ten "recommendations," a few of which contain numerous details and sub-parts. Only the first three principles are relevant for this paper, as the fourth concerns prevention of overindebtedness rather than its treatment. The first three principles, clearly reflecting the essence of Huls's earlier report, are (1) fair and equitable allocation of consumer credit risks, (2) provision of some form of discharge of indebtedness, rehabilitation, or "fresh start" for the

\footnotetext{
${ }^{14}$ Huls, supra note 3, at 228.

${ }^{15} I d$. at 226.

${ }^{16} I d$.

${ }^{17} \mathrm{Id}$. at 229.

${ }^{18} \mathrm{Id}$. at 226.

${ }^{19}$ INSOL International, Consumer Debt Report: Report of Findings and Recommendations (2001), online at http://www.insol.org/page/38/consumer-debt-report and http://www.insol.org/pdf/consdebt.pdf. Note that "consumer debtors" here include small business people, "natural persons . . . whose debts . . . however caused, (private or commercial) exceed their ability to repay within a reasonable period.” Id. at 3.
} 
debtor, and (3) extra-judicial rather than judicial proceedings where there are equally effective options available.

The first recommendation is the most substantial and detailed, calling on legislators to "enact laws to provide for a fair and equitable, efficient and cost-effective, accessible and transparent settlement and discharge of consumer and small business debts." ${ }^{20}$ The string of terms in this broadly encompassing opening submission is parsed to provide essential detail. "Fair and equitable" is defined to mean a "balanced approach" that recognizes, on the one hand, that the system "should not be abusive to debtors and not necessarily designed just to protect and maximise value for creditors," but, on the other hand, a debtor's entire available payment capacity should be available to creditors. Noting that resources should be reserved to debtors to allow them to maintain a "reasonable standard of living," the report does not elaborate on this vague concept, other than to call for assurances that "necessary living expenses ... of the debtor and his dependents can be met," with special attention given to "the high costs of housing." The period over which the debtor must apply best efforts to pay off debt "can be as long as seven or eight years," the report notes, but it "should not be over-extended” in light of the debtors' having already experienced financial hardship and deprivation during the years leading up to an overindebtedness case. INSOL's report encourages legislators to be mindful that " $[t]$ he risk that the debtor will not be able to cope on a limited budget . . . and will relapse into overspending, is realistic." Continuing to unpack the nest of defined terms, the report explains that "efficient" is meant to recognize that individual debtors "seldom have sizeable estates," so "[c]omplicated and time-consuming procedures should therefore be avoided." "Cost-effective" is primarily a function of access; that is, "debtor[s] should have easy access to the procedure without costs being an obstacle ... and without numerous or complicated formalities." Finally, "transparent" simply implies that proceedings are not secret; individual debtors and creditors should be able to follow cases concerning them.

The second and third recommendations envision multiple types of proceedings depending on the nature of the case. First, consumers might be offered a choice of a payment plan or immediate discharge, as the report posits "there is no benefit extending insolvency procedures for a longer period” for debtors with no disposable income and no prospects for an improved financial situation within a reasonable period. ${ }^{21}$ That being said, the report notes that "[a] debtor is not necessarily helped when a discharge is easily obtained without the underlying causes being solved or taken away."22 Conversely, given INSOL's general focus on business insolvency, the report suggests separate or alternative proceedings for small business entrepreneurs, whose cases might be far more complicated, with much larger debts, requiring “different approaches” such as an attempt at business rehabilitation. ${ }^{23}$

The entire second principle and its one detailed recommendation are devoted to the notion of offering a discharge of debt not paid through the debtor's best efforts plan: "legislators should offer consumer debtors a discharge of indebtedness as a tailpiece of a liquidation or rehabilitation procedure." 24 While this discharge should "not be seen as an easy way out," the

\footnotetext{
${ }^{20} \mathrm{Id}$. at $14-17$.

${ }^{21}$ Id. at 18 .

22 Id. at 19.

${ }^{23}$ Id. at $19-20$.

${ }^{24}$ Id. at $22-24$.
} 
INSOL report cautions that "[t]he barriers to obtain a discharge should . . . not be so high that the debtor is discouraged from using the procedure." 25 This discharge "should cover as many debts as possible," though common exceptions such as "maintenance agreements, fraud, court fines, taxes and student loans” are noted. Anti-abuse provisions to deny some debtors a discharge "should be limited and well-defined," generally confined to the "consequences of fraudulent activities by the debtor." 26 This recommendation also addresses the international effects of the proposed discharge. Recognizing the adoption in May 2000 of the Council Regulation (EC) No. $1346 / 2000$ on cross-border insolvency proceedings, a separate recommendation encourages legislators to ensure that the discharge (and other benefits of consumer insolvency laws) are "mutually recognized in other jurisdictions."27 Though it goes on to opine that, optimally, the various national laws "should aim at standardization and uniformity," the INSOL report backs away from this recommendation immediately, capitulating with the observation that "[o]verall uniformity or harmonization of consumer insolvency laws may not be a realistic objective.”28

The third principle carries forward another of the primary themes of Huls's earlier study, calling on legislators to "encourage extra-judicial or out-of-court proceedings for solving consumer and small business debts problems," and supporting this process through the provision of "sufficient competent and independent debt counseling." 29 The INSOL report argues that the major advantage of a non-judicial approach is that, compared to court proceedings, extra-judicial proceedings are less expensive and time consuming. The report endorses judicial cram-down provisions (imposing a plan on creditors against their will) where unanimous creditor acceptance is not obtained, especially if dissenting creditors" "position in and the outcome of extra-judicial proceedings are not materially different from judicial proceedings." ${ }^{30}$ Finally, the special problem of costs for debtor representation are mentioned, noting again that "[c]osts should never be an obstacle for a debtor to solve his debt problems through an extra-judicial procedure.”31

\section{C. iff Overindebtedness Report, DG Health \& Consumer Protection (2003)}

Ten years after the Consumer Policy Directorate General had commissioned the Huls study of overindebtedness, discussed above, that same DG (now of Health and Consumer Protection) followed up by commissioning a second study. Once again, the preeminent European scholars in this area were tapped for the study, led by Udo Reifner and his Institute for Financial Services in Hamburg (institut für finanzdienstleistungen, or "iff”), along with Nick Huls again, as well as Johanna Niemi-Kiesiläinen. ${ }^{32}$ The result of this study, the "iff report," begins by contrasting the continental and Anglo-American approaches to consumer debt relief, observing that the intervening years had shown that "European countries have somewhat different policy approaches to overindebtedness," in particular an emphasis on prevention rather

${ }^{25}$ Id. at 6.

${ }^{26} \mathrm{Id}$. at 24.

${ }^{27} \mathrm{Id}$. at 20.

${ }^{28} \mathrm{Id}$. at 21.

${ }^{29} \mathrm{Id}$. at 25-27.

${ }^{30} \mathrm{Id}$. at 25-26.

${ }^{31} \mathrm{Id}$. at 26.

${ }^{32}$ Udo Reifner, Johnanna Kiesiläinen, Nick Huls \& Helga Springeneer, Consumer Overindebtedness and Consumer Law in the European Union: Final Report 16-17 (Contract Reference No. B5-1000/02/000353) (2003), online at http://iaclaw.web.its.manchester.ac.uk/Research_papers/iff_OverindebtednessandConsumerLaw.pdf and http://news.iff-hh.de/media.php?id=1886. 
than treatment of overindebtedness. ${ }^{33}$ It goes on to analyze in great detail existing legislative mechanisms for both prevention and rehabilitation of overindebtedness, including the principles enunciated in both the earlier Huls study and the INSOL Consumer Debt Report. The iff report announces that INSOL's report "presents the international consensus about sound law and policy in insolvency matters" and concludes that it thus represents "the common core of consumer bankruptcy policies for the near future."34 The iff report distills five core principles of European consumer insolvency law: (1) rehabilitation by way of a broad discharge, (2) earned fresh start through a payment plan, which tends to be "onerous" to avoid moral hazard and public resistance to the institution of debt adjustment, (3) open access to debt adjustment proceedings without prohibitive costs, though restricted to those acting in "good faith," (4) availability of budget and debt counseling, and (5) preference for out-of-court or "pre-court" proceedings. 35

With respect to overindebtedness treatment legislation, the iff report represents an invaluable resource for charting the progress of what had by that point become a landslide of legislative activity in Europe on this topic. Surprisingly, after cataloguing the various national regimes, the iff report refuses to choose one system as reflecting "best practices," concluding that "[i]t is impossible to say at the moment that one system is better than the other. Therefore there is no basis for any kind of recommendation on harmonisation." ${ }^{\text {,6 }}$ Rather, the report remains largely descriptive, observing how the variety of evolving systems in Europe had begun to cohere around a "European model" for consumer debt relief. Identifying the core aspect of the European approach, the iff report notes that "European insolvency laws require the that new economic start is earned through a long and demanding payment plan."37 Taking a markedly more normative stance on this key issue, the report questions the demand for extended payment plans, arguing that it "seems to be more of a manifestation of the importance of 'good payment morals' than of economic interest of the creditors. The yields of the payment plans are never big and in most cases they are quite modest. Some studies have shown that the average outcome to creditors is about $15 \%$ of total debt outstanding. It requires quite a large amount of administrative and judicial work to draw up a plan and to monitor it. Therefore, the economic rationale of such plans sometimes seems questionable, this being most obvious in the case of zero-plans."38 Acknowledging that the requirement of payment plans serves a financialeducational purpose and likely "manifests the European moral attitude towards payment of debts," the iff report nonetheless provocatively concludes that "[i]t is probably time to ask whether it is sensible to make middle class people who have the resources to be productive members of society to live on the subsistence minimum for five years just to satisfy the jealousness of their neighbours." 39

The iff report's recommendations on insolvency legislation largely track those in the Huls study and the INSOL report, modified by a few comments based on the authors' detailed review of accumulated European experience with new national legislation. Three of these comments are most salient. First, with respect to exceptions to discharge, the iff report goes farther than its

\footnotetext{
${ }^{33}$ Id. at $14-15$.

${ }^{34} \mathrm{Id}$. at 45 .

${ }^{35} \mathrm{Id}$. at 247-48.

${ }^{36} \mathrm{Id}$. at 255.

${ }^{37} \mathrm{Id}$. at 167.

${ }^{38} \mathrm{Id}$.

${ }^{39}$ Id. at 167-68, 248.
} 
predecessors in arguing for a maximally broad discharge, proposing that "exceptions for taxes, fines, [and] damages are not recommended." 40 Second, this is the first report to suggest that guarantors of the debts implicated in a rehabilitation plan should receive some consideration beyond their own ability to seek a separate debt relief case. ${ }^{41}$ Third, on the perennial question of how long to require the debtor's best efforts, the iff report returns to Huls's original recommendation: It admits that five years had become the median length of payment plans, but suggests that three years would be preferable. ${ }^{42}$

\section{DG Enterprise Best Project: Restructuring, Bankruptcy and Fresh Start (2003)}

While the Consumer Policy DG was underwriting the iff report, the Enterprise DG was sponsoring another installment of its Lisbon Agenda "Best Procedure," this time relating to insolvency: the Best Project on Restructuring, Bankruptcy and a Fresh Start. ${ }^{43}$ Though this project focuses on small- and medium-sized businesses and on the effects of bankruptcy law (as opposed to overindebtedness relief law), many of the ideas in this Best Project's final report are equally applicable to natural persons not engaged in business.

Most importantly, this project reflects a solidified dedication to the basic notion of relief from oppressive debt through discharge. One of the report's key policy recommendations is that an "early discharge" should be available to debtors who have not acted fraudulently. ${ }^{44}$ Indeed, it suggests the need for a public campaign to change mindsets with respect to financial failure and to promote the notion of a fresh start for non-fraudulent debtors. ${ }^{45}$ The Finnish law on Adjustment of the Debts of a Private Individual, which requires a five-year payment plan, is specifically held up as a "good practice," as is the English policy transition in the Enterprise Act 2002, especially the reduction of the discharge period to one year, subject to a possible income payment order for up to three years. ${ }^{46}$

Further echoing the suggestions in the Huls, INSOL, and iff reports, the Best Project report recommends that entry thresholds for rehabilitation systems should be lowered, making these procedures more accessible. " In particular, the Best Project report criticizes the costs of rehabilitation systems, which are "often too expensive for small and medium-sized businesses." Complaining that "[c]osts are sometimes an obstacle” in seeking relief through formal insolvency proceedings, the report recommends that the procedures for rehabilitation should be simplified and thus cost less. ${ }^{48}$

\footnotetext{
${ }^{40}$ Id. at 250.

${ }^{41} \mathrm{Id}$. at 251-52.

${ }^{42} I d$. at 253.

${ }^{43}$ European Commission, Enterprise Directorate General, Best Project on Restructuring, Bankruptcy and a Fresh Start, Final Report of the Expert Group (2003), online at http://ec.europa.eu/enterprise/policies/sme/files/sme2chance/doc/failure_final_en.pdf.

${ }^{44}$ Id. $\S 5.3 .4$ (pp. 20-21); $§ 7.3 .4$ (p. 28).

${ }^{45}$ Id. $\S 6.2$ (pp. 23-24); § 7.3 .1 (p. 28).

${ }^{46} I d$. $\S \S 5.4 .1,5.4 .2$ (pp. 21-22). On the other hand, the chart at the end of the report indicates "full implementation" of this "early discharge” recommendation in Austria and Germany, both of which required 7 years of payments at this time. See Annex II at 33, see also id. at 37 (explicitly pointing out Austria's 7-year period).

47 Id. $\S 4.3 .2$ (p. 14); § 7.2 .4 (p. 27).

${ }^{48}$ Id. $\S 4.3 .4$ (p. 15), $\S \S 7.2 .3,7.2 .5$ (p. 27).
} 


\section{E. DG Employment “Debt Amnesty” Peer Review (2006)}

European Union authorities continued their search for best practices in the treatment of overindebtedness when, in October 2006, the European Parliament and Council launched a program called PROGRESS - the Community Programme for Employment and Social Solidarity. ${ }^{49}$ The program extends from 2007 to 2013 and provides financial backing for the EU's Lisbon Agenda objectives in, among other areas, social protection and inclusion. A "peer review" process is one of the vehicles of the PROGRESS program, by which Member States exchange information and experience on best practices for combating social exclusion.

In November 2006, the Dutch Ministry of Justice, Dutch Association of Credit Banks, and the Municipal Credit Bank in Rotterdam hosted a peer review of the Dutch system of overindebtedness treatment. ${ }^{50}$ Representatives of five other peer nations took part: Denmark, France, Latvia, Luxembourg, and Sweden. The exchange on the sophisticated and wellestablished Dutch model was free-ranging, with the observers often simply expressing either surprise or admiration for the Dutch approach in one or another area. Three comments from the reviewers are of particular note in terms of evolving supranational policy in this area. ${ }^{51}$

First, "[t]here was general agreement on the need to give people a fresh start after a reasonably short time, rather than after seven years or more as in some countries." The peer reviewers were "impressed" by the Dutch model of a clean slate after completion of a payment plan of only three years (as opposed to five or seven years elsewhere), which was "an eye-opener for several peer countries.” One explanation offered was that the short plan term might be counterbalanced by a smaller retained income allowance in the Netherlands. Some observers noted that "debtors are allowed a significantly higher retained income" in other countries, though, as discussed below, it may be that the peer reviewers were unaware of the strong disconnect between the "law in books" and the "law in action" in debtor budgeting by the Dutch courts. In any event, they speculated as to an intentional "correlation between the length of the probationary period and the amount of money that the debtor is allowed to keep."

Second, better support for debtors during court proceedings was noted as a need. Debtors in the Dutch system were often not represented before the court during formal proceedings and were insufficiently prepared for what was to come at the hearing, in particular the need to proffer certain financial information.

Third and finally, the observers emphasized the importance of examining the good faith of creditors by way of balance between debtors' and creditors' rights. If debtors were to be scrutinized for their good faith in incurring and dealing with their debts, why should not creditors, too, be subjected to an examination of their good faith in luring debtors into credit arrangements and extending credit under potentially irresponsible circumstances.

\footnotetext{
${ }^{49}$ See http://www.peer-review-social-inclusion.eu/general-information.

${ }^{50}$ European Commission, DG Employment, Social Affairs and Equal Opportunities, Amnesty of debts: Amicable Agreement and Statutory Solution, Minutes (2006), online at http://www.peer-review-social-inclusion.eu/peerreviews/2006/amnesty-of-debts-a-three-step-solution/minutes_en/download, and Short Report (2006), online at http://www.peer-review-social-inclusion.eu/peer-reviews/2006/amnesty-of-debts-a-three-step-solution/shortreport/download.

${ }^{51}$ See Minutes at 23-24, 26; Short Report at 3-5.
} 


\section{F. Council of Europe, Recommendation on Legal Solutions to Debt Problems (2007)}

Whereas the EU authorities' sponsorship of the recommendations discussed above focused on the broader economic and cross-border effects of overindebtedness, the most recent ${ }^{52}$ elaboration of principles accentuates the individual human rights aspects of this problem. This latest initiative comes from another quite compelling supranational body, the Council of Europe, which is charged with implementing the European Convention on Human Rights. Since 46 European states are signatories to the Convention, the Council of Europe's recommendations, albeit non-binding, are at least more far-reaching than those affecting the now 27 member states of the European Union.

At their 26th Conference, held in April 2005 in Helsinki, the European Ministers of Justice adopted Resolution No. 1 on Seeking Legal Solutions to Debt Problems in a Credit Society. ${ }^{53}$ In this Resolution, the Ministers expressed concern about the rising problem of social exclusion arising from overindebtedness in the modern credit societies of Europe. They asked the Council of Europe's decision-making body, the Committee of Ministers, to charge its European Committee on Legal Co-operation (CDCJ) with analyzing the variety of contributing factors to this problem and making recommendations for the best approaches toward solutions.

The CDCJ commissioned an expert report, ${ }^{54}$ prepared by eminent scholar Johanna NiemiKiesiläinen and her colleague, Ann-Sofie Henrikson. The report concluded with a list of recommendations, ${ }^{55}$ including several on the developing contours of overindebtedness legislation. Given Niemi-Kiesiläinen's co-authorship of the iff report, it is not surprising that her recommendations were based on and carried forward those in that earlier report (which itself was based on and carried forward the INSOL Consumer Debt Report principles and recommendations).$^{56}$ In response to this report, the Committee of Ministers created a Group of Specialists on Seeking Legal Solutions to Debt Problems (CJ-S-DEBT) and charged it with preparing recommendations for official adoption by the Council of Europe. A series of final recommendations and an explanatory memorandum emerged from this group in February 2007 ${ }^{57}$ and were adopted by the Committee of Ministers of the Council of Europe in June 2007.58

\footnotetext{
${ }^{52}$ Another, later study also mentions the key attributes of overindebtedness treatment regimes, but it does so only in summary fashion. See European Commission, Directorate-General for Employment, Social Affairs and Equal Opportunities, Towards a common operational European definition of over-indebtedness (February 2008) [hereafter, Common Definition], full report online at http://ec.europa.eu/social/BlobServlet?docId=5093\&langId=en; summary online at http://ec.europa.eu/social/BlobServlet?docId=762\&langId=en.

${ }^{53}$ http://www.coe.int/T/E/Legal_Affairs/Legal_co-operation/Conferences and highlevel_meetings/European_Ministers_of_Justice/MJU-26(2005)Res1E.pdf.

${ }^{54}$ Johanna Niemi-Kiesiläinen \& Ann-Sofie Henrikson, Bureau of the European Committee on Legal Co-Operation (CDCJ-BU), Report on Legal Solutions to Debt Problems In Credit Societies (2005), online at http://www.coe.int/t/e/legal_affairs/legal_co-operation/steering_committees/cdcj/cj_s_debt/CDCJBU_2005_11e\%20rev.pdf and http://www.coe.int/t/e/legal_affairs/legal_cooperation/steering_committees/cdcj/CJ_S_DEBT/.

${ }_{55}^{5}$ See id. § 6, p. 42.

${ }^{56}$ Id. at 5 .

${ }^{57}$ Final Activity Report of the Group of Specialist for Legal Solutions to Debt Problems (CJ-S-DEBT) (2007), online at http://www.coe.int/t/e/legal_affairs/legal_co-operation/steering_committees/cdcj/cj_s_debt/CJ-SDEBT\%20_2006_\%206\%20e\%20Final\%20-\%20web\%20version.pdf.

${ }^{58}$ Legal solutions to debt problems: Recommendation Rec(2007)8 and explanatory memorandum, online at https://wcd.coe.int/ViewDoc.jsp?id=1155927\&Site=CM\&BackColorInternet=9999CC\&BackColorIntranet=FFBB5 $\underline{5 \& B a c k C o l o r L o g g e d=F F A C 75 \#}$.
} 
Only the fourth of the five recommendations is relevant here. The first presents a broad working definition of "overindebtedness," the second addresses measures to prevent excessive consumer debt, the third deals with debtor protections from aggressive individual claim enforcement (e.g., property and wage exemptions), and the fifth concludes with comments on general implementation. With respect to the fourth recommendation - that the governments of member states "introduce mechanisms necessary to facilitate rehabilitation of over-indebted individuals and families and their reintegration into society" - the details of the Council's approach generally track those in Niemi-Kiesiläinen and Henrikson's expert report, with a few notable variations.

The fourth recommendation is broken down into several separate aspects of the "mechanisms necessary to facilitate rehabilitation." One of these is a rather broad exhortation to "encourag[e] effective financial and social inclusion of over-indebted individuals and families, in particular by promoting their access to the labour market." With reference to this point, the explanatory memorandum contains a nice encapsulation of the reasons modern European societies have chosen to offer and should expand offerings of debt relief:

Over-indebtedness may result in exclusion of individuals and families from society including a loss of motivation to be engaged in income-generating activities, exclusion from social activities and health problems. This is not only detrimental to the individuals and families concerned, but also to society as a whole as it suffers evident financial loss. The financial losses caused by overindebtedness include social security expenses, tax losses due to the over-indebted individuals being unemployed, medical costs, accommodation of those evicted from their homes, low recovery rates of creditors, the loss of members who could potentially contribute to the economy and the overall well-being of society. That is why one of the paramount objectives of rehabilitation should be social and financial inclusion of over-indebted individuals and families. ${ }^{59}$

As to the details of the recommended rehabilitation mechanisms, the Council of Europe's position differs only mildly from earlier suggestions. First, virtually axiomatic by this point, the importance of a broad discharge ${ }^{60}$ is again emphasized, though only "where other measures have proved to be ineffective." A cornerstone of the European approach to overindebtedness relief has always been and will remain that debtors should fulfill their obligations if at all possible, and freedom from legitimately incurred obligations is a privilege, potentially subject to abuse, that should therefore be a carefully guarded last resort. ${ }^{61}$ A preference for out-of-court arrangements supported by debt counselors is also reiterated in the Council's recommendations, noting that the goal of this approach was a desire "to find easier, faster, and cheaper solutions and to avoid an increased case load for the courts."62 Indeed, the need to limit individual creditors' ability to hinder such arrangements again figures prominently in the Council's recommendation, with a

\footnotetext{
${ }^{59}$ Id. ๆ 36 and fn. 3 (footnote moved to text).

${ }^{60}$ As for exceptions to discharge, the Council recommendation mentions without endorsing such national law exceptions as taxes, fines, and student loans. See Explanatory Memorandum 9 33. The final recommendation thus diverged from the expert report's suggestions that exceptions be limited to “maintenance payments to a debtor's child.” Niemi-Kiesiläinen \& Henrikson, supra note 54, § 6 at 42.

${ }^{61}$ See also Final Activity Report, supra note 57, ๆ 52, at 9.

${ }^{62}$ Explanatory Memorandum, supra note 58, ๆ 34.
} 
suggestion that "a competent body" might impose a settlement when no legitimate reason is provided by a creditor for refusing to respond. ${ }^{63}$

Effective access to relief procedures also figures among these recommendations, with a clarification that "effectiveness of access to such procedures implies not only that they should be free of charge (or low cost) and impartial, but also easily accessible on a practical level.",64 Though the expert report had mentioned the common requirement of good faith, ${ }^{65}$ the group of specialists' final activity report noted that they had excluded any notion of distinguishing between indebtedness arising from "good" and "bad" faith, at least in part due to problems with identifying reasonable core criteria for "good faith.",66

With respect to the requirement of an earned start through a payment plan, the Council's recommendation simply calls for plans to be "reasonable, in accordance with national practices, both in repayment obligations and in duration." The explanatory memorandum adds that "[w]hat may be considered 'reasonable' may vary from one member state to another," but it goes on to reaffirm that any plan "should ensure that amounts of payments as well as the duration of the plan do not deprive the debtor and/or his or her family of the ability to satisfy their basic needs with due regard to their human dignity." 67

One final recommendation raises an important point not emphasized earlier. The human rights notion of equality calls for similar treatment of similarly situated debtors in different regions of a country. Consequently, part of the fifth, "implementation” recommendation calls on member states to "ensur[e] uniformity" of policies relating to rehabilitation. The explanatory memorandum mentions the need to "ensure that all policy decision relating to debt management and treatment of over-indebted individuals and families are uniform and conform to an established countrywide standard, with a view to guaranteeing their equal treatment."68

\section{Recommendations and Their Reflection (Vel Non) in Evolving National Systems}

Between the Huls study in 1993 and the appearance of INSOL's Consumer Debt Report in 2001, Europe witnessed a flurry of activity in adoptions and reforms of consumer overindebtedness legislation and policy. The pace of new adoptions and reforms accelerated during and just after the formulation of the Council of Europe's 2007 Recommendation. How have these recommendations been reflected in the national legislative movements? This section extracts the clearest and most common principles and recommendations from the sources described above and tracks the trajectory of national legislative policy in terms of these issues.

\section{A. Discharge}

The most ubiquitous recommendation, on which there appears now to be complete unanimity, would have been viewed as a scandalous abdication of responsibility as recently as

\footnotetext{
${ }^{63}$ Id. 935.

${ }^{64}$ Id. ๆ 31.

${ }^{65}$ Niemi-Kiesiläinen and Henrikson, supra note 54, §5.3 at 29-30, § 6 at 42.

${ }^{66}$ Final Activity Report, supra note 57, at $₫ 27$ at 6.

${ }^{67}$ Explanatory Memorandum, supra note 58, ๆ 32.

${ }^{68}$ Id. \ 39.
} 
two decades ago. Every one of the sources surveyed here (and many others not surveyed) unambiguously recommends that national laws contain a mechanism for allowing debtors, even those not engaged in business, to seek personal and household rehabilitation through some sort of procedure that concludes with a discharge of part or most of their debts. The fear of moral hazard and "de-responsibilisation" is still present, and all sources impose some sort of rigorous quid pro quo for this relief. Nonetheless, it is extraordinary that such consensus seems to have emerged for abandoning the historical notion that debts must be paid, whatever the personal and social costs. A more nuanced appreciation has clearly taken hold in analyzing the balancing act involved in enforcing conventional, delictual, and even administrative obligations: pacta sunt servanda-requiescat in pace?

\section{Offer a legislative path to rehabilitation through discharge}

In 1990, only Denmark and the UK offered consumers a legislative path to court-imposed discharge ${ }^{69}$ of some portion of their debts. Today, 19 European states (18 of the 27 EU Member States and Norway) have adopted laws that allow individuals to seek a forced discharge of non-

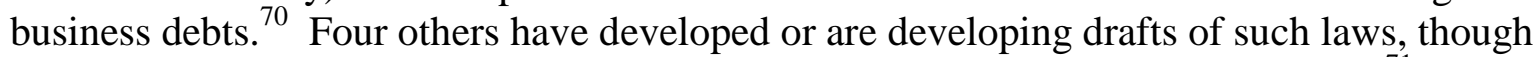
drafts have been rejected recently in the legislative process in at least two of these. ${ }^{71}$ Of course, this discharge revolution did not occur overnight. Between 1990 and 28 July 2010 (when the Greek legislature adopted the most recent such law), national legislatures adopted debt adjustment and discharge legislation in several distinct waves.

Denmark set the stage with its groundbreaking Greldssaneringslov, adopted 9 May 1984 (effective 1 July 1984), which added a new Part IV to its Bankruptcy Act (Konkurslov) to provide a rehabilitation and discharge procedure for individuals. Shortly thereafter, the long process of revising English insolvency law culminated in 1986 with the adoption of a new Insolvency Act with a bankruptcy procedure that offered an automatic discharge after three years, though the discharge period would later be reduced to one year with the adoption of the Enterprise Act 2002 (effective 1 April 2004). Completing the first wave, France moved toward a discharge law with the adoption of the Loi Neiertz on 31 December 1989 (effective 1 March 1990), adding a series of sections to the Consumer Code (Code de la consommation) for treating overindebtedness of individuals. Though this first law did little more than encourage and facilitate mild consensual debt restructuring, the stage was set for the introduction of a broad

\footnotetext{
${ }^{69}$ France adopted an overindebtedness law in 1989, but it did not offer a discharge until 1999, as discussed below.

${ }^{70}$ Indeed, within the United Kingdom, two parallel, independent regimes offer a consumer debt discharge, in England \& Wales and in Scotland, though the former will be the focus of this paper. See, e.g., Donna McKenzie Skene \& Adrian Walters, Consumer Bankruptcy Law Reform in Great Britain, 80 AM. BANKR. L.J. 477 (2006). I do not include Ireland here, which provides yet another independent path to discharge, but only following a 12-year waiting period after conclusion of bankruptcy proceedings. Most commentators, including in Ireland, do not consider this to be reasonably ejusdem generis with the other laws described here, and I agree that Ireland should be grouped with the countries that have failed to heed even this most fundamental recommendation. See, e.g., Law Reform Commission, Consultation Paper (LRC CP 56-2009), Personal Debt Management and Debt Enforcement s. 3(E)(1)(b) (Sept. 2009), online at http://www.lawreform.ie/Consultation_Papers_Published/Default.134.html.

${ }^{71}$ Draft bills were presented to and rejected by the legislatures in Romania (spring 2010) and Lithuania (spring 2009), though the government has pledged to renew the process in Lithuania in mid-2010. Drafts have been pending for years in Italy, including the latest pending as of May 2010. In Hungary, the government has been working for several years on a draft bill, and as of mid-2010, its latest proposal remains mired in the review process of a newly elected government. Among the EU's neighbors, Ukraine and Russia have also considered or are in the process of considering draft bills on "bankruptcy of physical persons," as well.
} 
discharge provision in the law of 29 July 1998 (effective 1 February 1999), which later expanded into Europe’s most “liberal” discharge procedure with the law of 1 August 2003 (effective 25 February 2004) and most recently the law of 1 July 2010 (effective 1 November 2010), as described below.

Denmark's move set in motion a second wave of new discharge legislation, inspiring the other Scandinavian countries to adopt laws with approaches quite similar to the Danish model. Norway adopted a freestanding law on debt adjustment (Gjeldsordningslov) on 17 July 1992 (effective 1 January 1993), Finland followed suit with a similar freestanding law on 25 January 1993 (effective 8 February 1993), and Sweden rounded out the Scandinavian peninsula with its Skuldsaneringslag on 5 May 1994 (effective 1 July 1994). Further south, extended exploratory processes came to fruition in Austria and Germany around this same time. Austria amended its bankruptcy law (Konkursordnung) in 1993 to add a discharge procedure for private individuals (Privatkonkurs), effective 1 January 1995. Germany completely revised its bankruptcy law (Insolvenzordnung) on 5 October 1994, though the effective date was put off for nearly five years (to 1 January 1999) to allow the justice system to prepare for an expected onslaught of consumer cases seeking relief under the innovative new provisions on discharge, for which the Germans even coined a new term: Restschuldbefreiung.

A few years later, a third wave of debt adjustment laws washed over the Benelux region. The Netherlands initiated this third wave on 25 June 1998 by adopting the Law on Debt Adjustment of Natural Persons (Wet schuldsanering natuurlijke personen, generally referred to by its abbreviation, Wsnp). Effective 1 December 1998, the Wsnp took the Germanic approach of adding a third and final title to the Dutch bankruptcy law (Faillissementswet) to implement a new procedure specifically for individuals seeking discharge. Belgian legislation soon followed on 5 July 1998 (effective 1 January 1999), amending the enforcement provisions of the Belgian Judicial Code (Gerechtelijk Wetboek/Code judiciaire) to provide a process for debt adjustment and discharge. Finally, on 8 December 2000, Luxembourg followed the French approach of setting up a free-standing law to provide for relief along lines very similar to those in the new Belgian law, though the Luxembourgish law's effective date was delayed for nearly a year until the Grand Ducal regulations were signed on 12 October 2001 putting the framework for the new procedure into place.

The mid-2000s witnessed a fourth large wave of activity, as reformulated general insolvency laws with new provisions for individual discharge emerged in the far eastern and western reaches of Europe. Such redesigned insolvency acts appeared in Estonia on 22 January 2003 (effective 1 January 2004), Portugal on 18 March 2004 (effective September 2004), Slovakia on 9 December 2004 (effective 1 January 2006), the Czech Republic on 9 May 2006 (originally planned to become effective 1 July 2007, but later postponed to 1 January 2008), Latvia on 1 November 2007 (effective 1 January 2008), Slovenia on 17 December 2007 (effective 1 October 2008), and Poland on 5 December 2008 (effective 31 March 2009).

At the beginning of this new decade, Greece finally abandoned its position as one of the few remaining holdouts without a consumer debt relief law. On 28 July 2010, a new freestanding law on non-judicial debt negotiation and judicial debt adjustment, including discharge, emerged from the Greek legislature. The provisions on out-of-court negotiation are effective as of 1 September 2010, though the effectiveness of the provisions for an in-court adjustment 
process is delayed to 3 January 2011 to allow the judicial authorities to prepare for this new procedure. Within the next few years, one can confidently predict that we will see new individual discharge laws in Romania, Lithuania, Hungary, and Italy, all of whom recently have produced drafts of such legislation. ${ }^{72}$ In light of the growing majority of EU Member States with debt adjustment and discharge laws, these countries' legislatures should be able to muster the political will to overcome resistance from the banking sector, especially in light of the challenges European societies are facing in the current recession. This will leave only a few stragglers who now stand clearly outside the mainstream on debt relief. Reform projects have been under consideration for years in Ireland, ${ }^{73}$ with its highly criticized debt collection and bankruptcy regime, and while Spain managed to adopt a new bankruptcy law in July 2003 (effective September 2004), it fails to provide for a discharge. As for the final three EU Member StatesBulgaria, Cyprus, and Malta-publicly available evidence suggests these countries have no consumer discharge law and are not in the process of developing one. One hopes that studies like this one will reveal to these "comfortably numb" countries that their legislation lags behind that of their EU neighbors, and before the close of this decade, the first unanimous recommendation from the experts - to have a law that offers overindebted individuals a discharge of at least some of their debts-will have been unanimously embraced.

\section{Discharge debts broadly, with few exceptions}

While the experts agree on the desirability of discharge generally, their various recommendations are considerably less united with respect to the breadth of the discharge; that is, how many types of debts should be excluded from the discharge for public policy or other reasons. The academic experts are in favor of very broad discharge with very few exceptions, while INSOL and the Council of Europe are more standoffish on this delicate political question. The experts seems to agree that maintenance and support debts for children and perhaps even former spouses should be excluded, and national laws all but universally refuse to allow parents to escape the financial obligations of parenthood (there are isolated exceptions to even this principle). The experts are also relatively unified in excluding fines from the discharge (as well as debts incurred through fraud, when the existence of such debts does not bar relief altogether), though a number of national laws discharge even fines.

Significant disagreement surfaces with respect to non-punitive debts to the state, especially taxes, and delictual obligations resulting from the debtor's gross negligence. In his first set of recommendations, Huls originally accepts an exclusion for gross negligence delicts, as well as taxes and debts to public utilities, though the iff study, in which Huls later participated, concludes that "exceptions for taxes, fines, [and] damages are not recommended." Another member of the iff report team reached a similar conclusion years later, as Johanna NiemiKiesiläinen's expert report to the Council of Europe suggests restricting excluded debts to just one: "maintenance payments to a debtor's child." The Council of Europe and its Group of Specialists, however, make no recommendation with respect to such an ultra-inclusive discharge. The final explanatory memorandum to the Council's recommendations mentions (without endorsing) such national law exceptions as taxes, fines, and even student loans. The INSOL

\footnotetext{
${ }^{72}$ See supra note 71.

${ }^{73}$ See, e.g., Law Reform Commission, supra note 70, ch. 5 (recommending the adoption of an "earned debt discharge” through a payment plan, much like other European overindebtedness laws).
} 
report also remains relatively neutral on this point, simply noting the common exceptions for maintenance, fraud, fines, taxes, and student loans.

National laws have largely sided with the academic experts on these debts, offering an expansive discharge of tax, delict, and study debts. With respect to taxes and similar public debts, most legislatures have forthrightly foregone their right to pursue public debts just as they deprived creditors of their right to collect private debts. A few of the more recent laws, however, maintain the state's right to pursue tax and similar debts in the public interest, subjecting only private creditors to the discharge. The new Greek law (art. 1, para. 2), for example, excepts taxes and fees owed to the central government and local authorities, and the Latvian law (sec. 177(2)) also excepts tax debts. Only a handful of laws exclude delictual obligations, and even then only a few specific kinds of delicts. ${ }^{74}$ With respect to study loans for living expenses or, increasingly in recent years, tuition fees, such loans are excepted from discharge in the Netherlands, England, and Sweden, though a separate Swedish government agency administers the complex student-loan repayment program (the Centrala Studiestödsnämnden, commonly abbreviated “CSN”). This agency offers forbearances and possibly even forgiveness to borrowers in financial difficulty. Problems with student loan collections for which the CSN has not offered forbearance have been significant in Sweden, however. ${ }^{75}$

Beyond these and a few other minor variations, existing laws in Europe seem to adhere to the recommendation to avoid eroding the discharge with exceptions. Europe thus stands in stark contrast with the United States, where the discharge in consumer bankruptcy cases (in both liquidation and payment plan cases) has long been riddled with exceptions. ${ }^{76}$ Not only most taxes, fines, fraudulent debts, criminal restitution orders, maintenance obligations, and student loans are excepted from the U.S. discharge, but also debts related to property settlements in divorce cases, delictual obligations for "willful and malicious injury," and drunk driving debts are also excluded, among a few others. A total of 19 broad categories of debt are specifically identified in U.S. law as not subject to discharge. While it is understandable that governments would attempt to avoid a public outcry by freeing debtors from certain sensitive debts, the clear European trend to limit these exclusions is commendable and should continue.

\section{B. Extra-judicial solutions}

The experts are also firmly united in their desire that debtors should have access to professional debt counseling, and that it is preferable for debtors and creditors to work out situations of distress in informal, or at least extra-judicial, processes (most likely with the assistance of such counseling). The only surprising point here is what appears to be a further rhetorical degradation of the bedrock notion of pacta sunt servanda; that is, experts do not base

\footnotetext{
${ }^{74}$ In the few laws that exclude delictual liabilities from discharge, the level of culpability required to exclude these claims varies. The insolvency acts in Germany (s. 302), Austria (s. 215), Czech Republic (s. 416(1)) and Estonia (s. 176(2)) exclude only damages from intentional delicts, while Belgian law (Gerechtelijk Wetboek/Code judiciaire art. $1675 / 13$ § 3) excepts unintentional delictual obligations, but only for reparations for bodily injuries. The French law (Code de la consommation art. 331-1(2)) excepts only reparations orders entered in favor of victims of crime committed by the debtor.

${ }^{75}$ See Jason Kilborn, Out with the New, In with the Old: As Sweden Aggressively Streamlines Its Consumer Bankruptcy System, Have U.S. Reformers Fallen Off the Learning Curve?, 80 AM. BANKR. L.J. 435, 449 n.86 (2007)

${ }^{76}$ See 11 U.S. Code ss. 523(a), 1328(a).
} 
this recommendation on a desire to leave private contractual obligations in the hands of the private contracting parties, respecting the sanctity of private ordering. Rather, both of the two major recommendations that offer an explanation of why states should prefer out-of-court arrangements base their suggestions on cost-savings and efficiency. The INSOL report argues for a non-judicial approach because such proceedings are less expensive and time consuming, while the Council of Europe similarly couches its recommendation in a desire "to find easier, faster, and cheaper solutions and to avoid an increased case load for the courts." One would have expected at least a bit of the traditional encomium for honoring private contracts, and it is quite telling that only efficiency and avoiding court overload are offered as justifications for this unanimous policy. In stark contrast to commentary from the 1990s, pacta sunt servanda is no longer present even in spirit, let alone in name.

\section{Offer low-cost or cost-free debt counseling and representation}

Most national legislatures have shared the experts' view that the treatment of overindebtedness should begin as soon as possible, when mild intervention and financial counseling might suffice to put debtors back on the right track. Virtually every country in Northern and Western Europe offers expansive credit counseling to overindebted individuals, though the sources and types of and funding for such counseling differ substantially from country to country. ${ }^{77}$ In Southern and Eastern Europe, credit counseling networks are generally either non-existent or are relatively under-developed, though a few selected countries, especially Hungary, have well-developed programs of counseling and even financial education. Of particular note, the new Greek law on overindebtedness ${ }^{78}$ seems to lay the foundation for more developed credit counseling and intermediation with creditors, though this will doubtless take some time. A similar effort has been underway in Portugal since 31 March 2009, by which the Justice Ministry accredits credit counseling agencies to aid overindebted individuals in order to bridge the gap between these people and agencies that might help them to achieve workouts with creditors. $^{79}$

In the many cases where counseling is insufficient, and a formal insolvency case is opened, however, national laws too often leave debtors without adequate representation or support in the formal, legal process. Only in the largely non-judicial system in Sweden ${ }^{80}$ do counselors systematically continue to support debtors in formal insolvency proceedings; elsewhere, even where free legal advice is available in civil matters, it is generally not extended to in-court insolvency and overindebtedness cases. ${ }^{81}$ The Debt Amnesty Peer Review observers specifically noted the problem of poor debtor representation in the formal process, and failing to offer such support may make the entire procedure not “easily accessible on a practical level," as called for by the Council of Europe. This is an area where both existing systems and those under consideration could be improved in a very meaningful way, and very few countries have effectively responded to expert calls for greater low-cost support of debtors in the formal system.

\footnotetext{
${ }^{77}$ For a nice overview of credit counseling activities in Europe, see the iff report, supra note 32, at 199-216; see also Debt advice in Europe, http://www.sfz.uni-mainz.de/2626.php (describing counseling in 29 European countries).

${ }^{78}$ See especially section 2(3).

${ }^{79}$ Information on this program is available from the Justice Ministry's website at http://www.mj.gov.pt/sections/newhome/sobreendividamento-e/.

${ }^{80}$ See Kilborn, supra note 75, at 443 (note 46 and accompanying text).

${ }^{81}$ See iff report, supra note 32, at 208-10.
} 


\section{Require negotiation with creditors before opening a formal case?}

One extremely common way in which national laws express their preference for extrajudicial solutions is not only to support counseling and negotiation, but to require it as a precondition to entry into the formal debt adjustment system. In one form or another, such a prerequisite to opening an overindebtedness case was included in every law adopted in 2000 or before, with the exception of those in Denmark and the UK. One explanation for these two exceptions is that these two countries are among the few that lacked broad scale credit counseling when their overindebtedness laws became effective. Continuing weakness of counseling systems in Eastern and Southern Europe partly explains the absence of a pre-court negotiation requirement in most of the laws adopted after 2000; that is, in Estonia, Portugal, Slovakia, the Czech Republic, Latvia, Slovenia and Poland. The one exception is the most recently adopted law: Greece reverted to the 20th-century approach of requiring an attempt at a negotiated settlement before seeking formal relief.

Another explanation for the Danish resistance to this requirement is more fundamental. On a basic policy level, the Danish commission that developed the debt adjustment law concluded that the business-bankruptcy concept of "forced compromise" (tvangsakkord) was unsuitable for consumer debtors. The debt adjustment system was designed to force creditors in every case to accept a legally imposed reasonably compromise in order to rehabilitate consumers struggling with hopeless debt. These debtors most likely would be unable to offer a significant and relatively quick dividend to creditors, so resort to a negotiation predestined for failure made little sense. ${ }^{82}$ In 2007, Swedish policymakers joined their Danish predecessors in scrapping this requirement. They did so in response to years of criticism of the long delays and fruitless waste of labor in the required consensual renegotiation stage, which even many creditor representatives considered "nearly meaningless." 83

Other countries have sought different solutions to the problem of low rates of out-ofcourt compromise. First, France designed its system with a brilliant built-in incentive for at least commercial lenders to agree to informal settlements: the system is administered largely under the auspices of the Banque de France, which proposes the debt adjustment plans and has lobbied creditor groups aggressively to cooperate with the out-of-court process. ${ }^{84}$ A persuasive negotiator is particularly helpful in situations like these, in which consumer debtors have little leverage and little to offer to entice creditors into offering needed relief.

Second, resistance to out-of-court settlement often comes from public agencies, such as tax authorities and fine collection bureaux, and Belgium and the Netherlands have dealt with this particular problem by directly engaging the source. In Belgium, the finance ministry and social security administration early on developed a policy of categorically refusing to agree to any settlement that involved remitting any portion of debt to the public fisc. The Prime Minister vociferously criticized this stance, but legislative intervention was ultimately necessary to break the logjam. In the law of 15 December 2005, the first major reform of the Belgian system, a new

\footnotetext{
${ }^{82}$ See Jason Kilborn, Twenty-Five Years of Consumer Bankruptcy in Continental Europe: Internalizing Negative Externalities and Humanizing Justice in Denmark, 18 INT’L. INSOL. REV. 155, 168-69 (2009)

${ }^{83}$ See Kilborn, supra note 75, at 458-59

${ }^{84}$ See Jason Kilborn, La Responsabilisation de l'Economie: What the United States Can Learn From the New French Law on Consumer Overindebtedness, 26 MiCH. J. INT’L L. 619, 638-39 (2005)
} 
section was added to the provisions on amicable settlements, specifically authorizing public creditors to agree to a remission of debt. ${ }^{85}$ It is not possible with the scarce publicly available statistics on the Belgian system to gauge the effect of this new explicit legal authorization, but one hopes public authorities will accept the legislature's invitation to be more cooperative.

A somewhat similar story played out in the Netherlands, where amicable settlement enjoyed a long and successful history. In the early 1990s, however, a precipitous decline occurred in the rate of settlements, a decline that accelerated after adoption of the new Dutch debt adjustment law in $1998 .^{86}$ By 2004, only 9\% of proposed out-of-court plans were accepted by creditors. This troubling trend was reversed in part by counseling agencies' abandoning their unbending focus on pushing every debtor into a voluntary arrangement. Debtors that are clearly destined for the formal debt adjustment system are now prepared for and routed directly to that system, with a certificate attesting that any attempt at a voluntary arrangement would be pointless. This allows counselors to focus their limited resources and enhance success rates in cases that are better candidates for a voluntary arrangement. More to the point here, the national coordinating association for credit counseling (the NVVK) noticed that one-third of unsuccessful negotiations failed as a result of rejection by the Central Fine and Collection Agency (Centraal Justitieel Incassobureau, generally called by its acronym, CJIB). The NVVK brokered an agreement with the CJIB that seems to have had a dramatic impact on the success rate for negotiated adjustments: The rate of successful negotiations climbed to $18 \%$ in $2006,22 \%$ in 2007, and $33 \%$ in 2008, remaining at $30.5 \%$ in $2009 .{ }^{87}$ Other factors may have contributed to this spike in success rates, including a substantial revision of the debt adjustment law itself in 2008, but clearly among the primary influences here were the concerted efforts of the NVVK to reform counseling procedures and convince the CJIB to stop undermining the process.

Perhaps the absence of a pre-court negotiation requirement in the post-2000 laws (with the exception of the new Greek law) indicates that governments have internalized the lessons of Denmark, Sweden, and the Netherlands. Perhaps they have concluded that Denmark and Sweden had the right approach to this issue, since even in jurisdictions like the Netherlands that are most supportive of out-of-court workouts, the success rate of such negations is still well below 50\%. While extra-judicial solutions might well save time and money in the cases where creditors can be convinced to accept a compromise, if the overwhelming majority of these cases end up proceeding to the judicial stage anyway, the delays and expenses of a required negotiation stage are not only superfluous, they are seriously detrimental. As Swedish reformers observed, deluging counselors with cases in which no settlement can reasonably be expected has the doubly negative effect of diluting already scarce counseling resources. States should encourage extra-judicial solutions, but not by distracting counselors from the few cases in which a settlement is a reasonable possibility. The challenge for the future here is achieving the delicate balance between favoring out-of-court adjustments while focusing counseling resources on the clear minority of cases that are reasonable candidates for voluntary settlement.

\footnotetext{
${ }^{85}$ Gerechtelijk Wetboek/Code judiciaire art. 1675/10 s. 3 bis.

${ }^{86}$ For a particularly insightful discussion of why adoption of a more closely monitored and predictable alternative in the formal law has shifted creditors' incentives toward refusing informal arrangements, see Nick Huls, Nadja Jungmann \& Bert Niemeijer, Can Voluntary Debt Settlement and Consumer Bankruptcy Coexist? The Development of Dutch Insolvency Law, in CONSUMER BANKRUPTCY IN GlOBAL PERSPECTIVE 269, 273, 274-75 \& tbl. 1 (Johanna Niemi-Kiesiläinen, Iain Ramsay \& William Whitford eds., 2003).

${ }^{87}$ Statistics and other information are available on the NVVK's website, http://www.nvvk.eu/.
} 


\section{Provide a mechanism for overcoming creditor resistance to settlement}

Another more direct way of overcoming creditor resistance and achieving greater success for extra-judicial compromises is by imposing such settlements on creditors. If a requisite majority of creditors accepts an out-of-court workout proposal, it might be "crammed down" on dissenters, to use the U.S. terminology. Huls, the INSOL report, and the Council of Europe all suggest that some form of imposed agreement should be considered to support extra-judicial adjustment proceedings. Huls suggests cram-down on dissenters if a plan is supported by $75 \%$ of creditors. The INSOL report vaguely endorses cram-down, especially when dissenting creditors' "position in and the outcome of extra-judicial proceedings are not materially different from judicial proceedings." The Council of Europe also recommends limiting creditors' ability to hinder out-of-court workouts "unreasonably," though the explanatory memorandum seems to reserve cram-down to situations where creditors fail to respond to a settlement offer at all. Forcing creditors to accept a reasonable extra-judicial plan might be a solid first step toward accepting the recommendation of the Debt Amnesty Peer Review observers, who emphasized the need to demand good faith from creditors, as well. If, as was repeatedly observed by Swedish and Belgian reformers, creditors reject plans on no basis other than obstinacy or a general opposition to compromise, this hardly seems to satisfy a call for good faith from creditors.

Despite solid support for this approach, the debtor's proposed plan accepted by a majority of creditors can be "crammed down" on a dissenting minority only in Germany, the Netherlands, Austria, Sweden (since 2007), and France (since November 2010), as well as in England through the bankruptcy alternative of "individual voluntary arrangements." 88 Practically, the meager resources of most debtors are seldom sufficient to fund a plan that can entice acceptance from anywhere near a majority of creditors. The historical experience in Germany and the Netherlands in particular has shown that true cram-down of the debtor's proposal has been the rare exception. Despite some success for a unique type of cram-down in Austria, the successful aspect of that system can hardly be called a "cram down" in light of the similarities between the imposed plan and an ordinary discharge proceeding. Recent reforms in Swedish and French law more powerfully leverage non-judicial actors and may represent a better approach going forward.

The German law allows the court to impose the debtor's proposed plan on creditors if the plan is accepted by majorities in both number of creditors and amount of claims. ${ }^{89}$ The notion of a second consideration of the failed out-of-court proposal, however, was criticized from the very beginning. A federal-state working group reported in 2000 that this cram-down process often represented a "pure formality" because in most cases "it is clear from the beginning that the necessary majority of creditors supporting the plan cannot be achieved.” After courts in 2001 were given the option of discarding this stage and proceeding directly to the formal insolvency case, the cram-down provision faded into desuetude. ${ }^{90}$

\footnotetext{
${ }^{88}$ Though the processes in France, Belgium, and Luxembourg also often lead to something similar to a judicial cram-down, this approach is substantially different from “cram-down” as described here. In these three countries, the court imposes its own plan, generally subject to greater restrictions than an out-of-court plan would be (particularly regarding discharge of debt) and possibly subject to greater protections for the debtor, as well, in terms of limitations on plan length and resources to be left to the debtor during the repayment period.

${ }^{89}$ Insolvenzordnung ss. 305-309.

${ }^{90}$ See Jason Kilborn, The Innovative German Approach to Consumer Debt Relief: Revolutionary Changes in German Law, and Surprising Lessons for the United States, 24 Nw. J. INT’L L. \& BuS. 257, 276-77 (2004)
} 
Both the legal requirements for cram-down, and the infrequent use of that process, are very similar in the Netherlands. Dutch debtors can (but are not required to) request that a court impose a proposed voluntary payment plan (akkoord) on dissenting creditors if a simple majority in number and amount of claims has voted in favor of the plan. Alternatively, the court can cram down the plan on one or more creditors with particularly large claims if three-quarters in number of preferred and unsecured creditors vote in favor of the plan, and the refusal of the larger claimant(s) to approve the plan was "unreasonable" given the circumstances, particularly the percentage that the rejecting creditor(s) stand(s) to recover if the formal process continues without a "voluntary" plan. This combination of detailed provisions vividly reflects the recommendations of INSOL and the Council of Europe, but the theoretically attractive idea has enjoyed very little practical success. This "akkoord" process was invoked successfully in only $1 \%$ of cases in the first two years of the new Dutch law, and less than $4 \%$ of cases thereafter. This is still true, even after a reform effective 1 January 2008 attempted to strengthen the forced agreement provisions. The primary reason why such agreements are rejected is still that debtors simply have too little to offer in out-of-court proposals. ${ }^{91}$

Austrian law allows two attempts at a judicially imposed plan. The first, more restrictive attempt at a "forced agreement" (Zwangsausgleich, after 2010 called a Sanierungsplan) has also proven moribund, as it imposes the unrealistic requirement that the debtor promise creditors at least $20 \%$ of their claims within up to five years. ${ }^{92}$ In the second, more successful approach, the debtor can ask the court to impose a majority-approved "payment plan” (Zahlungsplan) on a dissenting minority of creditors, and this plan must simply promise to apply an amount, equal to all of the debtor's anticipated non-exempt income over the next five years, to fund a payment plan. Given the requirement of ceding non-exempt income, and the fact that the payments of this amount can be stretched out over seven years, this plan is barely distinguishable from the wholly coercive seven-year discharge proceedings that will ensue if creditors fail to agree. Thus, it is surprising, though only mildly so, that consistently in about $70 \%$ of all cases, majorities of creditors have tended to accept inevitable defeat and capitulate to such "payment plans.",93

\footnotetext{
${ }^{91}$ See Marijke von Bergh et al., Raad voor Rechtsbijstand, Monitor Wsnp: Vijfde meting 25 \& tbl. 3.8b, 39, 66-67 (2009), online at http://www.wsnp.rvr.org/pdf/rapp_2042_Monitor\%20WSNP_5e\%20meting_web.pdf. After 1 January 2008, an additional provision on dwangakkoord (forced agreement) allows the debtor to request that the court force a creditor to accept the debtor's proposed out-of-court plan "if the creditor could not reasonably have refused” to accept the debtor's compromise plan, "in light of the imbalance between the [creditor's] interest ... . and the interests of the debtor and of the other creditors who will be injured by the rejection." Faillissementswet art. 287a ( $c f$. id. art. 332, the in-court akkoord procedure). "Forced agreement” has been requested in only about 1000 cases in the first two years of its availability (compared to over 18,000 formal Wsnp cases initiated), and only about one-third of these requests have been granted (though 40-50\% have been withdrawn without a decision from the court). See von Bergh, supra this note, at 39; Marijke von Bergh et al., Raad voor Rechtsbijstand, Monitor Wsnp: Zesde meting 31-32 (2010), online at http://www.wsnp.rvr.org/pdf/Monitor\%20Wsnp\%206e\%20meting.pdf. ${ }^{92}$ Konkursordnung (after July 2010, Insolvenzordnung) s. 141. The acceptance rate for such agreements has fallen steadily from just 3\% in 2000 to less than 0.5\% in 2008. Georg E. Kodek, Fourteen Years of Consumer Bankruptcy in Austria 12 (unpublished manuscript on file with author); Thomas Berghuber, Ausweg gesucht!: Schulden und Privatkonkurs 75-76 (5th ed. 2007), https://broschuerenservice.bmask.gv.at/PubAttachments/ Privatkonkurs\%202007.pdf; Georg Kodek, Handbuch Privatkonkurs 1324 at p. 145 (Wien 2002).

${ }^{93}$ See Konkursordnung (after July 2010, Insolvenzordnung) ss. 147, 293; Berghuber, supra note 92, at 76-78; Kodek, supra note 92, at 12. The primary distinctions between the "payment plan" and fully coercive discharge proceedings are that the latter requires a $10 \%$ minimum dividend to creditors, the debtor's non-exempt assets are
} 
While the German, Dutch, and Austrian laws engage the court to force dissenting creditors to compromise (sacrificing some of the desired time- and resource-savings of extrajudicial solutions), the latest bold move in Sweden and France is to remove the courts from the process almost entirely through non-judicial cram-down. In its original form, the Swedish debt adjustment law set up a three-step process: Step one was a required private negotiation with creditors, supported by budget counselors. When this negotiation failed, debtors would submit an application for relief to the state Enforcement Agency, who would draw up a payment plan following statutory guidelines to be presented to creditors for another vote in "step two." If creditors rejected this debt adjustment plan, the Enforcement Agency would send that plan to the court for judicial review and all but inevitable cram-down in "step three." As mentioned above, Sweden scrapped the "step one" private negotiation as a waste of time and counterproductive distraction for debt counselors. At the same time, effective 1 January 2007, Swedish lawmakers scrapped the judicial third step of the process, also. Like the debt counselors in step one, the courts had complained of wasting time and resources in step three on the very common cases where creditors had no reasonable basis for objecting to the proposed payment plan. Creditors reportedly objected on such abstract bases as “oppos[ition] to debt adjustment in principle," but the courts upheld the Enforcement Agency's proposed plans in $90-95 \%$ of cases. Ultimately, a reform report suggested that court review of the Enforcement Agency's plan had proven to be little more than a "pure formality," so the legislature responded by removing the formality. Some lawmakers voiced concern about allowing an administrative agency to deprive creditors of their property and contract rights without judicial process, potentially violating these creditors' rights under the European Convention for the Protection of Human Rights and Fundamental Freedoms. Because creditors could still access the court system via an appeal to challenge the Enforcement Agency's determinations, however, this concern was allayed, and the system has continued to function quite well in the ensuing years. ${ }^{94}$

An even more aggressive form of non-judicial cram-down was voted into French law, effective 1 November 2010. ${ }^{95}$ Somewhat like in Sweden, the French process is commenced with the filing of a petition with a regional "commission on individual overindebtedness," administered principally under the auspices of the Banque de France. The commission acts as a sort of hybrid between debt counselor and administrative tribunal, since its goal is to draw up a debt adjustment plan that can be voluntarily accepted by creditors, but it has the power to "recommend" that a court impose relief measures on creditors if they fail to agree. The rate of success in convincing creditors to accept voluntary measures has fallen from about $70 \%$ of all administered cases in 2000 to 55\% in 2008 and 2009, though this still represents an impressive success rate in the first instance. Of the remaining cases, just over half are now routed to an immediate liquidation-and-discharge system (discussed below), and just under half have been routed to a court for all but automatic judicial cram-down of the commission's recommendation. About $60 \%$ of the commissions' recommendations call for a global moratorium and reexamination after two years (so-called “extraordinary measures”), whereas about $40 \%$ more or less pass along the commission's proposed payment plan for court imposition on creditors (socalled "ordinary measures”). "More or less," because the content of a court-imposed plan cannot

liquidated before the discharge process begins, and the debtor's actual, not projected, disposable income is ceded to a trustee, who has some responsibility for monitoring the debtor.

${ }^{94}$ See Kilborn, supra note 75, at 455, 460-61.

${ }^{95}$ Loi no. 2010-737 of 1 July 2010, JORF no. 0151 of 2 July 2010. 
include a remission of debt, as do at least some commission-brokered plans. ${ }^{96}$ The innovation in the 2010 reform law is to do away with the judicial step for recommended ordinary measures. After 1 November 2010, the commissions will be able on their own authority to impose plans that include only ordinary measures. ${ }^{97}$ Creditors (or the debtor) can appeal to the execution court against the commission-imposed measures, ${ }^{98}$ but like in Sweden, appeal is the only means of recourse against ordinary measures of relief in France, as well.

The failure of the German, Austrian, and Dutch approaches should cast serious doubt on the inclusion of cram-down provisions in future laws that rely on majority creditor support. The experience in these countries confirms that plan negotiations usually fail either because no majority is likely to accept the debtor's inevitably meager offering, or because one or a few creditors with large claims refuse to support the process, likely with no rational economic basis. If creditor resistance to the preferred out-of-court solution is to be achieved, a more aggressive approach to cram-down should be pursued. At least along the lines of the original Swedish and French laws, courts without creditor support should be empowered in summary proceedings to impose reasonable plans developed by state-sponsored or perhaps even state-authorized negotiators. Better yet, states attracted by the notion of imposing extra-judicial workouts should learn from Swedish and French experience and keep the entire process out of the courts. If creditors are unhappy with an extra-judicial resolution, they should be able to appeal to the courts to vindicate their rights, but given the small economic stakes involved for creditors, they can be expected simply to capitulate to the reality of debtors' limited resources and the "pure formality” of engaging the courts to confirm that reality.

\section{Ensure low-cost access to debt adjustment procedures}

For a system designed to deal with financial shortfalls, it is not surprising to see the emphatic recommendation that costs should be kept to a minimum and should in any event not hinder access to needed relief. This is explicit and unambiguous in Huls, the INSOL report, and the Council of Europe's explanatory memorandum. Indeed, it also appears in the Best Project on Restructuring, which along with the INSOL report highlights an important cause and effect relationship: costs are often a function of the procedures chosen, and avoiding superfluous and inefficient procedural formalities is an important factor in keeping costs down.

Path dependency is a real hindrance here. All of the current overindebtedness systems were developed in light of, and perhaps even along with, business insolvency procedures, but too often, the formalities and processes of a business insolvency, even in liquidation, are all but inappropriate for non-business cases. When administering a complex case and liquidating and distributing an estate worth many thousands of Euros or more, broad publicity and trustees and claims verification and meetings of creditors and similar traditional insolvency procedures make some sense. When addressing small business cases, and especially non-business overindebtedness, with small or even non-existent estates, these same formalities even in simplified form serve little more than a ceremonial function, while adding significant expense to the case.

\footnotetext{
${ }^{96}$ See Kilborn, supra note 84, at 636-40, 646-54.

${ }^{97}$ Code de la consommation art. L331-7.

${ }^{98}$ Code de la consommation art. L332-2.
} 
Balancing the need for necessary procedures and formalities with efficiency is a serious challenge, but nearly three decades of European experience now reveals some important lessons on how to strike the proper balance. Western Europe has developed some creative ways of dealing with costs as a barrier to entry and to keeping costs down, while the newer Southern and Eastern European systems appear to be struggling with these issues.

Formal overindebtedness procedures generally involve three kinds of distinct costs. ${ }^{99}$ The first is for representation of debtors before, during, and after the formal case. As discussed above, this is too often dealt with by not providing sufficient representation at all. Many countries assign responsibility for debtors' extra-judicial representation to public or private debt counselors or volunteer consumer organizations. For the great bulk of debtors who cannot afford to hire private attorneys, almost all countries leave debtors completely unrepresented in the formal, in-court portion of the process. ${ }^{100}$ The formal process creates a second series of costs, general administration expenses, including not only overhead costs for the general operation of the relevant administrative and judicial bodies, but also case-specific expenses, such as those related to conducting meetings of creditors and verification of claims, as well as publication, photocopying, formal service or mailing of invitations to such meetings, voting ballots, and other case announcements. In the general civil context, such costs are usually required to be paid (or at least defrayed) upon commencement of the case through case-initiation or filing fees, but in the overindebtedness context, the petitioner seeking financial relief is often not in a position to make a large up-front payment of fees. Finally, the often most substantial cost of debt adjustment procedures encompasses the remuneration to be paid to a trustee for implementing and administering the multi-year payment plan. Even in cases where the debtor makes little or no payment of excess income, the minimum trustee fee for administering the plan for three to six years or more can be the most significant expense in any overindebtedness case, running well over $€ 1000$, and often multiples of that figure.

Several of the newer consumer insolvency systems adopted after 2000 have not heeded the recommendation about simplifying procedures and avoiding cost barriers to relief. Even where cost is not immediately the problem, bureaucratic inefficiency and formalism alone can hamper the system's effectiveness. Judicial inefficiency has been identified as among the principal hindrances of the consumer discharge provisions of the new insolvency code in Portugal. ${ }^{101}$ Cost has been an immediate problem, however, in a few of the Eastern European systems, as these laws commonly require debtors to pay-or prove that they will be able with future income to pay-either court costs or the trustee's fees, or both. Debtors who are unable to do so face immediate case dismissal. In Slovakia, for example, barely 150 cases have been opened under the consumer discharge provisions during the first three-and-a-half years of the new Slovak Insolvency Act. One likely explanation for this lies in the fact that a case is dismissed if the debtor's income is insufficient to cover the trustee's fee. ${ }^{102}$ The Latvian law

\footnotetext{
99 See iff report, supra note 32, at 193-96.

${ }^{100}$ Unlike in most of the rest of Europe, legal aid appears to be available to debtors in Slovenia. See Helena Kocmur, Stečajev bi bilo še več, če bi ljudje vedeli zanje, Delo.si (1 Jan. 2010), online at http://www.delo.si/clanek/98198.

${ }^{101}$ See Catarina Frade, Overindebtedness and Unemployment in Portugal: The Fable of the Grasshopper and the Ant, in Overindebtedness as a Barrier to Labour Market Access in Europe: Challenges and Ways Forward 36, 38 (2004), online at http://www.asb-gmbh.at/ecdn/index.php?option=com_docman\&task=doc _view\&gid=177.

102 Slovak Insolvency Act s. 171(A).
} 
requires the debtor's petition to demonstrate specifically that administrative costs have been covered in order for a case to be opened. ${ }^{103}$ The Polish law contains a similar provision ${ }^{104}$ for the few debtors who manage to satisfy its other very restrictive entry requirements (see below). The most recently adopted law, in Greece, contains no mention of costs, but given the law's consumer-protection orientation, one hopes that Greek authorities will not allow cost to be a barrier to entry.

In the mature systems in Western Europe, cost issues have been dealt with generally quite effectively through state subsidies and other cost-allocation strategies, as well as cost reduction through simplification. Many countries simply do not require debtors to pay any filing fee for overindebtedness cases. In the Scandinavian states, along with France, Belgium, and Luxembourg, general case administration expenses are treated as part of the overall social support system, to be absorbed into overall budgets for social services and the judiciary. In many of these same states, debtors administer their own plans, with minimal or no oversight by a trustee. Even in Denmark and Finland, where a trustee does administer payment plans, the trustee's fee is largely covered by the state for debtors with insufficient disposable income to cover this expense. In these and other systems with trustees, for debtors with sufficient income to produce a distribution, creditors indirectly pay the trustee's fee, as the fee is generally withheld from money that would otherwise be distributed to creditors.

Germany and Austria leave the burden of court costs on debtors, but these two countries have taken very different approaches to that burden. In Germany, before a 2001 reform, the overwhelming majority of consumer insolvency cases were treated in the traditional way: dismissal for "lack of estate" to cover administrative costs. The German legislature responded quickly and sensitively to this problem in 2001 by adopting the "forbearance model," by which case opening and administration fees would be deferred until after the debtor's completion of the multi-year rehabilitation plan. ${ }^{105}$ The debt for these fees is not subject to discharge, though given the depressed financial state of many debtors even after their discharge, the states' (Länder) judiciary budgets often end up bearing the brunt of these deferred expenses. Austria, in contrast, has held firm on its "economic benefit" perspective of allowing relief only to those debtors who can actually pay both court costs and a substantial amount to their creditors. A case can be opened in Austria despite insufficient assets to cover administrative costs, and debtors requesting a "cost advance" (Kostenvorschuss) must meet the extra requirements of having unsuccessfully sought an extra-judicial arrangement with creditors and making a second, in-court compromise offer. ${ }^{106}$ Though costs have been aggressively reduced in recent years, Austrian debtors face a bigger hurdle than this: they must convince the court that their future income will be sufficient

\footnotetext{
${ }^{103}$ Latvian Insolvency Act ss. 152(1)(2), 154(3)(9)-(10).

${ }^{104}$ See Polish Bankruptcy and Reorganization Act s. 13.

105 See Insolvenzordnung ss. 4a-4d, 26(1), 298; Kilborn, supra note 90, at 278-79 \& n. 129. The Estonian law takes a somewhat similar approach, allowing consumer cases to avoid the ordinary dismissal for lack of assets to cover costs, but instead of deferring those costs, the Estonian law seems to make no further provision for their payment after a discharge case has been opened. Cf. Estonian Bankruptcy Act ss. 29(1) (calling for dismissal for insufficient assets to cover costs), and 171 (directing the court to open a discharge case despite the insufficiency of assets to cover costs).

${ }^{106}$ Konkursordnung (after July 2010, Insolvenzordnung) s. 183.
} 
to cover court costs and offer creditors a $10 \%$ dividend on their claims. ${ }^{107}$ In any case, Austrian consumers cannot obtain a discharge without repaying these advanced court costs as well as the 10\% creditor dividend (absent certain specific, compelling, exceptional circumstances).

Belgium developed a particularly creative and insightful approach to allocating cost. Belgian legislators were especially sensitive to hampering access to relief for low-income debtors. Rather than allocating the burden of these costs to either impecunious debtors or already strained state coffers, legislators reasoned that the costs of administering an overindebtedness system should be most fairly and effectively assigned to the very creditors who, at least in large part, bore responsibility for the predicament of overindebtedness faced by the poorest of debtors. Moreover, the supply side of the consumer credit market had benefited handsomely at the expense of consumers, leveraged by the cost-savings of using credit scoring instead of careful underwriting and diffusing the expected defaults across large portfolios of consumer loans. Belgian legislators thus seized upon a model to control cost and expand debtor access while creating a desired negative incentive on excessively risky lending: they created a fund from a small new tax assessed only on that portion of the total consumer lending portfolio in default as of the end of each year. While trustees in Belgium (as elsewhere) are generally paid by deducting their fees from distributions to creditors, this special fund is available to pay the trustee fee for cases in which the debtor's income is insufficient even to cover that fee. ${ }^{108}$

In addition to carefully considering cost distribution, lawmakers have sought to reduce administrative costs by reforming and simplifying the procedures in virtually all of the systems put in place before 2000. Where trustees are appointed to distribute the debtor's excess income, their fees are carefully regulated according to a sliding scale, and distributions to creditors generally take place only once per year, to reduce administrative inconvenience and cost. In one other mild but important innovation, Germany, Austria, and the Netherlands have made greater use of the internet to distribute official announcements regarding consumer insolvency cases, thus avoiding significant photocopying and delivery expenses. ${ }^{109}$ Along similar lines, a new Belgian law of 6 April 2010 allows for a number of debt adjustment notices to be delivered through simpler, informal means, without the unnecessary formality of judicial certification. Further simplification reforms have been on the drafting table in Germany for years now, and a final push for such reform is expected from the justice ministry in the late fall of 2010.

Other countries have made even more large-scale efforts to reduce unnecessary formality and complexity. In 2007, Sweden radically restructured its three-step system with the express goal of making its process simpler, more efficient, and thus more effective. ${ }^{110}$ Especially in the time- and labor-intensive process of modifying plans already underway, the Swedish reform removed the entire burden from the judiciary and refocused it on the Enforcement Agency, the administrative actor best suited to handle this task efficiently. The Dutch reform of 2008 was also expressly designed to simplify the process and reduce the burden of excess administrative

\footnotetext{
107 Though it doesn't mention court costs, the Czech law is similar, directing the court to reject a debt relief petition unless it is convinced that unsecured creditors will receive at least a 30\% dividend. Czech Insolvency Act s. 395(1)(a); see also s. 415 (offering a hardship exception for debtors who fail to produce the 30\% dividend).

${ }^{108}$ See Jason Kilborn, Continuity, Change, and Innovation in Emerging Consumer Bankruptcy Systems: Belgium and Luxembourg, 14 AM. BANKR. INST. L. REV. 69, 103-06 (2006).

109 See, e.g., Insolvenzordnung s. 9, www.insolvenzbekanntmachungen.de.

${ }^{110}$ See Kilborn, supra note 75, at 457-61.
} 
complexity. A number of time-consuming and expensive procedures that in practice were used infrequently or not at all were either simplified (like the elimination of the flexible saneringsplan and refocus on the standard three-year statutory plan) or scrapped altogether. ${ }^{111}$ A particularly prominent example is the former requirement of a formal hearing for verifying creditors' claims. After the reform, the court, commissioner, and trustee can elect to convene such a meeting only in the relatively few cases in which distributions to creditors are expected, avoiding the process of claims verification in most cases altogether. ${ }^{112}$

Cost concerns also motivated the latest reform step in England \& Wales, which restructured the multi-option menu of debt-relief options as of 6 April 2009. Before then, the $£ 370$ fee for bankruptcy and the severe limitations of the alternative, "county court administration orders,” effectively prevented many low-income debtors from seeking relief. Now, for individual debtors owing less than $£ 15,000$ and having no more than $£ 50$ in disposable monthly income or $£ 300$ gross assets, a less expensive (£90) administrative proceeding is available from the state Insolvency Service: a "debt relief order." Aside from the income and asset restrictions, the terms of a DRO are very much like those in an ordinary bankruptcy case, offering a discharge of unpaid debt after one year, but without the formalities and expenses of the court-based bankruptcy procedure. This new vehicle was specifically designed to make relief available to those for whom cost would otherwise have been a barrier. ${ }^{113}$

Most recently, effective 1 November 2010, a reform in France has even more significantly reduced the burden on the judiciary and the expense to the state of the French debt relief system. As mentioned above, the commissions in charge of administering the overindebtedness system now have expanded power to impose certain debt adjustment provisions without court intervention. Moreover, in a particularly striking move, the already extraordinary "procedure of personal re-establishment" (discussed in greater detail below) has been made even more efficient. Available since February 2004, this process offers the most hopelessly overindebted petitioners an almost immediate discharge after simple liquidation of available assets, with no observation period or payment plan. As the number of cases routed by the commissions to this liquidation procedure grew, so did the administrative burden on the courts to catalogue and verify claims against these debtors and to survey their available assets. ${ }^{114}$ To alleviate this unnecessary burden, the 2010 reform allows the commissions to recommend a personal re-establishment without liquidation of assets in cases where the debtor possesses only household assets that are necessary, of no market value, or the value of which would be "manifestly disproportionate" to the costs of sale. In such cases, which almost by definition will represent the great bulk of personal reestablishments, unless a creditor affirmatively contests the relief, the court need only confirm the commission's recommendation and announce an immediate case closure and discharge. ${ }^{115}$

\footnotetext{
${ }^{111}$ See Raad voor Rechtsbijstand 's Hertogenbosch, Bureau Wsnp, De Wsnp per 1 januari 2008: Wat wijzigt er? (October 2007), online at http://www.mvz.nl/docs_mvz/watverandert_wsnp.pdf.

${ }^{112}$ This is a common practice in the United States, as well, where creditors are invited to submit proofs of claim only after the trustee establishes that assets will be available for distribution to creditors.

${ }^{113}$ See Insolvency Service, Guide to Debt Relief Orders, http://www.insolvency.gov.uk/pdfs/guidanceleafletspdf/ droguide.pdf.

${ }^{114}$ See Kilborn, supra note 84, at 658-60.

${ }^{115}$ See Code de la consommation arts. 330-1(1), 332-5.
} 
While the French system is unique among its European counterparts, this latest reform of one of the oldest existing overindebtedness systems shows just how far modern European legislators might be prepared to go to reduce formalities and costs to increase access. On the one hand, imposing an appointed trustee to monitor the debtor during the course of a multi-year payment plan improves creditor confidence in the system. ${ }^{116}$ On the other hand, as the iff report observes, the trustee's fee in particular is a very substantial cost that seldom produces an equivalent real economic return to creditors. The progression of French reforms reminds us that using traditional bankruptcy provisions like liquidations and trustees is perhaps a foolish consistency in a system where many cases will involve little or no distribution. The Cork Report established that avoiding wasteful collections costs is one of the desired benefits of an overindebtedness system. While three to six years of wasted trustee fees is certainly better than endless enforcement actions by individual creditors, the most recent series of reforms challenges other European policymakers to consider whether even those needless costs might be avoided with no great loss to systemic integrity. A new attitude is called for, especially in Austria and the newer systems that continue to set up cost barriers to access to overindebtedness relief. The costs of close scrutiny of debtors are not warranted by a few more drops of blood squeezed from stones - or, more likely, not squeezed from them. Legislators in Sweden, the Netherlands, Germany, France, and Belgium have set an example to be emulated with respect to slashing unnecessary costs and putting the weight of necessary costs where it belongs, either on the creditors, who have usually contributed most significantly to debt problems, or on society, whose direct and indirect benefits from overindebtedness relief systems are among the primary justifications for the existence of such systems.

\section{Ensure open access through broad eligibility}

Early on, Huls realized the potential for over-zealous restrictions on access to debt relief. He recommends that national laws avoid barriers to entry, such as minimum debt levels, and in particular that they should avoid rigid application of a "good faith" requirement to exclude debtors based on subjective lifestyle judgments: "good faith is supposed, bad faith must be proven.” The INSOL report seconds this position, suggesting that only fraudulent activities should bar relief, and generally, barriers to obtaining a discharge should not be so high as to discourage debtors from using the procedure. Likewise, lowering entry thresholds is among the few relevant suggestions of the Best Project on Bankruptcy, which encourages lawmakers to make these procedures more accessible. Finally, the Council of Europe also urges ease of access "on a practical level." Specifically with respect to a "good faith" requirement, the Council of Europe's Group of Specialists rejected any such entry criterion given the inherent subjectivity of this concept and the difficulty of identifying reasonable core criteria for "good faith."

The key recommendations thus all mention a concern with open access and broad eligibility, though this is the issue that perhaps most divides the national laws from each other and from the expert recommenders. Early concerns persist as to the potential for abuse of these systems by those who might view them as an easy way to evade their legitimate obligations. Therefore, unsurprisingly, every law permits relief only for those who are in fact "insolvent" or "overindebted." Though the definition of this key entry criterion varies mildly among jurisdictions, a clear consensus position limits relief to those unable to pay their debts within a

\footnotetext{
${ }^{116}$ See Huls \& Jungmann \& Niemeijer, supra note 86.
} 
reasonable period with reasonable effort. Beyond this, though, the earlier laws incorporated additional, often substantial barriers to entry to guard against abuse of the new, radical form of discharge relief, and those restrictions have been relaxed only slightly as society embraced the new systems. With only a few exceptions, the more recent laws have largely adopted the recommended policy of open access, at least in terms of eligibility criteria (though the cost issue remains a stumbling block for several of these laws, as discussed above).

\section{Minimum debt levels, reasonableness, and other entry restrictions}

Path dependency seems also to be an issue here, as the oldest debt adjustment laws are the most restrictive with respect to access, setting up quite substantial barriers to entry that limit access to a relatively narrow segment of the overindebted population. Because these systems were in the vanguard of a new movement challenging the age-old notion of pacta sunt servanda, it is unsurprising that they would have been particularly sensitive to controlling potential abuse and moral hazard by limiting access to only "deserving” debtors. Unfortunately, these early access restrictions have remained, despite criticism and subsequent reform, and a few of the newer laws have adopted a similarly restrictive approach to eligibility.

Among the very first to adopt debt adjustment laws, the Scandinavian nations continue to limit access to relief to only a few hopelessly indebted people who clearly have no possibility of returning to financial health on their own within a reasonable time. In the pioneering Danish system, access is predicated on two criteria: First, the debtor must be in a state of "qualified insolvency," with no prospect of being able to pay off debts in full in the near future (generally 5 years). Though no minimum debt level appears in the statute, the courts generally require at least 250,000 crowns (about €25,000) of debt for able-bodied debtors and 100,000 crowns (about $€ 10,000)$ for retirees and disabled people to establish this factor. The question whether available income is sufficient to service this debt is a function of the debtor's way of life and how she or he chooses to use his or her resources. The courts can deny access to debtors who dedicate more than a "reasonable" amount of their income to living expenses (especially housing and cars), based on nothing more than the discretionary judgment of individual courts and judges. A final aspect of this test is a prediction of the debtor's financial situation over the next 5 years. The courts can bar entry to debtors whose economic situation is "unclear" and who might be able to regain their financial footing in the foreseeable future. Thus, temporarily unemployed ablebodied debtors are often denied entry.

A second, "subjective" set of access criteria originally required the court to overcome a negative presumption that relief would not generally be appropriate; that is, the court had to be convinced that the debtor's "behavior and circumstances otherwise speak in favor" of debt adjustment. The statute guides this judgment with a series of enumerated items to be considered, such as (1) the likelihood that the debtor would not remain in or return to a perpetual state of indebtedness after a discharge, (2) a long-term and active struggle with an unmanageable debt, rather than passive resignation or relatively recent vintage difficulties; and (3) a relative scarcity of fines, penalties, and “irresponsible" debts among the debtor's debt load. A reform of the Danish law, effective in 2005, reversed the presumption, now in favor of admission unless consideration of the enumerated factors "suggests decisively against” relief. This change only 
mildly broadened access, however, and admission rates in the ensuing years have actually fallen, dropping below $40 \%$ of all petitions in $2009 .^{117}$

The other Scandinavian laws largely adopted the Danish entry restrictions, with only mild differences of emphasis and interpretation. In both Norway and Sweden, access is allowed only to debtors whose financial situation is marked by "qualified insolvency," and for whom granting relief is otherwise "reasonable" and not morally objectionable. ${ }^{118}$ In the most recent reevaluation of the Swedish law, reformers proposed to reverse the statutory presumption (as in Denmark) to favor relief unless circumstances suggest otherwise. While this proposal was rejected, the Swedish Supreme Court has long signaled its view that petitions should be denied only if the record sufficiently supports rejection. Nonetheless, the Swedish courts reject a fairly consistent average of about $40 \%$ of all petitions. ${ }^{119}$ The Finnish law focuses more on the reasons for the onset of overindebtedness (unemployment or illness versus overconsumption or speculative investment), with particular attention to weeding out debtors who have "run into debt in an irresponsible way or with a debt arrangement procedure in mind."120

Outside Scandinavia, access to relief is generally much less jealously guarded, with two isolated exceptions. First, Poland's recent law is among the most restrictive, allowing access only to debtors whose insolvency resulted from exceptional circumstances entirely beyond their control. $^{121}$ In the first year of the new Polish law (from 31 March 2009 to 31 March 2010), only 14 debtors were admitted, from among over 1000 petitions. ${ }^{122}$ Elsewhere, a second unique type of restriction, as mentioned above, is a minimum payment requirement, which can exclude debtors even after they have been "provisionally" admitted to the procedure and labored for years on a minimum budget to pay their debts. To earn relief, debtors in Austria and the Czech Republic must produce a minimum dividend to creditors over the life of their debt adjustment plans-10\% of creditors' claims in Austria, and 30\% in the Czech Republic! While both laws provide for a hardship discharge in exceptional circumstances, these minimum dividend rules doubtless exclude many "honest but unfortunate” debtors from relief. Years of demands from debt counselors and other social justice organizations to eliminate this requirement in Austria have been consistently rejected by the justice ministry. ${ }^{123}$

\footnotetext{
117 See Kilborn, supra note 82, at 166-69, 175-76.

118 See Kilborn, supra note 75, at 444-48; Hans Petter Graver, Consumer Bankruptcy: A Right or a Privilege? The Role of the Courts in Establishing Moral Standards of Economic Conduct, 20 J. CONS. POL'y 162, 165-66, 170-72 (1997); Johanna Niemi-Kiesiläinen, Consumer Bankruptcy in Comparison: Do We Cure a Market Failure or a Social Problem?, 37 OsGoOdE HALL L.J. 473, 493 (1999) (suggesting narrow interpretation of the moral escape clause for Norwegian cases that are "støtande.," or against good repayment morality).

${ }^{119}$ See Kilborn, supra note 75, at 445-46 \& n. 60.

120 See Niemi-Kiesiläinen, supra note 118, at 491-92.

${ }^{121}$ Polish Bankruptcy Act s. 491[3], first clause.

122 See Sylwia Czubkowska \& Klara Klinger, Upadłość niedostepna dla zwykłego konsumenta - z ustawy skorzystało tylko 14 osób, Dziennik Gazeta Prawna (31 Mar. 2010), online at http://prawo.gazetaprawna.pl/artykuly/ 410219,upadlosc_niedostepna_dla_zwyklego_konsumenta_z_ustawy_skorzystalo_tylko_14_osob.html.

123 The latest reform proposals, restarted in March 2010, envision broadening the hardship discharge exceptions for debtors who have not managed to pay their creditors a 10\% dividend by the end of a 7- or 10-year plan period. See, e.g., ASB Schuldnerberatungen GmbH, Schuldenreport 2010, at 12 (July 2010), online at http://www.asbgmbh.at/asb/equal/newssystem/asb_schuldenreport_2010_END.pdf.
} 


\section{Good faith}

Only two countries' laws explicitly require "good faith" for entry into the system: France and the Netherlands. ${ }^{124}$ The French commissions and courts early on struggled with nonuniformity in interpreting the vague notion of "good faith," but they have generally taken a quite liberal approach, adhering to Huls's recommendation to avoid rigid construction of this requirement. Fewer than $10 \%$ of all filings for overindebtedness relief are rejected by the commissions, and most of these rejections result from a lack of overindebtedness or the presence of professional debts. ${ }^{125}$

In the Netherlands, in contrast, the more court-centered approach of the Dutch debt adjustment law imposed a significant burden on the judiciary, and many judges chafed at this increased workload. Perhaps as a result, between 1999 and 2005, the rejection rate climbed from less than 5\% to about 15\% of all petitions, and "not in good faith" accounted for the great majority of these dismissals (84\% in 2005, 74\% in 2008). ${ }^{126}$ As in France, the rejection rate has varied markedly among different Dutch courts (e.g., less than 5\% in Groningen, but nearly 30\% in Rotterdam). The entryway to relief has become seemingly even narrower following a reform, effective 1 January 2008, that was explicitly designed to limit the number of debtors admitted to the system. ${ }^{127}$ The revised law requires (rather than just allowing) dismissal if the debtor fails to establish his or her good faith (essentially setting up a mild presumption of bad faith, which debtors have to overcome) or if the debtor owes certain kinds of relatively recent debts related to criminal conviction. ${ }^{128}$ Placing the burden on the debtor to establish his bona fides flies in the face of Huls's cogent recommendation that good faith should be presumed. Moreover, the legislative history of the new law invites judges to use their discretion to further restrict entry to debtors who are "not ready" to comply with their obligations during the debt adjustment, such as homeless debtors and those with "psycho-social problems" such as addictions, unless the debtor makes clear that such problems are "under control." Early post-reform admissions statistics suggest that the courts' practices have changed little if at all post-reform, though a striking $40 \%$ drop-off in filings in 2008 and 2009 might indicate some self-filtering by debtors out of the debt adjustment system for fear that their applications will be rejected.

Foreshadowing the Council of Europe's conclusion on the difficulties with a good faith criterion, lawmakers in both Belgium and Luxembourg explicitly refused to follow the French model of requiring good faith, in part because of the problem of widely varying interpretation of the notion in the French system. Instead, the laws in Belgium and Luxembourg bar access only for debtors who have "manifestly organized [their] insolvency." Consistent with

\footnotetext{
${ }^{124}$ In addition to the minimum dividend requirement discussed immediately above, the Czech law (s. 395(1)(a)) directs the court to reject the petition if the judge discerns a "dishonest intent" from the debtor, which might be equivalent to a general good faith requirement, depending upon how the courts apply this provision. While the Slovak law (s. 167) requires that the debtor express an "honest" intention to make reasonable efforts at repayment, this does not seem at all to resemble a general good faith requirement.

${ }^{125}$ See Kilborn, supra note 84, at 636 n. 115.

${ }^{126}$ See von Bergh et al., supra note 91, at 34-35. For a magisterial study of the concept and application of "good faith" in the Dutch debt adjustment system, see Arnoud Noordam, Schuldsanering en geode trouw (academisch proefschrift, Vrije Universiteit te Amsterdam 2007).

${ }^{127}$ See Jan C. van Apeldoorn, The 'Fresh Start' for Individual Debtors: Social, Moral and Practical Issues, 17 INT’L INSOL. REV. 57, 68-70 (2008).

${ }^{128}$ Faillissementswet art. 288.
} 
recommendations from Huls and INSOL, the legislative history of these laws reveals that they were designed to exclude only debtors who had acted fraudulently or criminally in undermining their creditors’ rights. ${ }^{129}$

Beyond those mentioned above, the remaining laws place few restrictions on entry to and exit from the discharge procedure. Every law excludes relief for a few categories of particularly "undeserving” debtors, such as those recently convicted of certain crimes or those who have defrauded creditors or provided false information in the bankruptcy process. Beyond this narrow range of cases, however, open access is the norm. Throwing the door wide open to those seeking to evade their obligations is a difficult recommendation to follow. This is an inherently political issue, and legislators will continue to face serious pressure from creditor interests and traditionalists who prefer to admit only the narrowest of exceptions to the traditional "thou shalt pay thy debts" rule. States will likely continue to disagree as to the range of debtors to whom relief should be offered, but the modern trend is definitely to follow the recommendation for broader eligibility.

\section{E. Require best efforts as a quid pro quo, but make payment plans reasonable}

The factor that most prominently distinguishes European overindebtedness law from U.S. consumer bankruptcy, even in the "Anglo-American" jurisdiction of England \& Wales, is the demand made of debtors to earn their fresh start in Europe, as opposed to the more common "get-out-of-jail-free” immediate discharge in U.S. "Chapter 7." The European insistence on income payment orders or payment plans has been criticized in both the INSOL report and the iff report as a fruitless (or insufficiently fruitful) squandering of substantial administrative resources that suppresses debtor initiative for far too long, but the requirement persists and can be expected to persist in most cases. One can today confidently say "most cases," as experience has shown that the required "payment" is often no more than theoretical where it is required, and in France, more and more debtors are not required to make any future income payments at all. By and large national laws have adhered to the recommendation to ensure human dignity for debtors laboring under debt adjustment plans, though this continues to be a contentious and dynamic issue.

\section{Plans for all debtors, or only those with payment capacity?}

Both Huls and the INSOL report mention the possibility of "zero plans" or alternatives to a payment plan for debtors with no payment capacity. While this might seem scandalous to traditionalists and creditor interests, adding insult to injury in a system already undermining the bedrock notion of fulfilling one's obligations, it has quietly and increasingly become a reality throughout Europe.

So-called "zero plans” have constituted a significant portion of all "payment plans” from the earliest days. In Denmark, the commission that produced the first Continental debt adjustment law speculated that cases offering an immediate full discharge in exchange for no payment from the debtor would be "relatively few," but such cases turned out to represent nearly one-third of all confirmed cases. ${ }^{130}$ Likewise in Sweden, the possibility of an immediate full discharge for debtors with no payment capacity was acknowledged from the very beginning, and

\footnotetext{
${ }^{129}$ See Kilborn, supra note 108, at 80-81 n. 55.

${ }^{130}$ See Kilborn, supra note 82, at 171 n.110.
} 
at least $30-40 \%$ of all administered cases have involved "zero proposals" with no payments to creditors. ${ }^{131}$ Dutch lawmakers, too, anticipated from the very beginning that many debtors would be unable to pay anything substantial beyond the trustee's fee. On the one hand, very little use has been made of a special fast-track procedure for discharge after one year for cases where "it is not reasonably anticipated that the debtor can fulfill his or her obligations in full or in part." ${ }^{132}$ On the other hand, a majority (and perhaps as high as two-thirds) of Dutch payment plans to date have been purely symbolic, paying only the trustee fee, if even that. ${ }^{133}$

The notion of a "payment" plan is even more often illusory in Germany, and in both Germany and Belgium, early resistance to such plans has waned or been crushed. Lawmakers in Germany also were prepared for creditors to receive nothing or nearly nothing in most consumer cases, as they have roundly and repeatedly rejected proposals to require a minimum dividend to creditors (as is still required in Austria). While courts in the early years resisted so-called "zero plans," the majority of lower courts, and all appellate courts of the Länder that dealt with this issue, soon concluded that so-called "zero plans" should be allowed if that represents the debtor's best efforts. ${ }^{134}$ Today, an estimated $80 \%$ of all cases in Germany produce no dividend to creditors at all.

Belgian lawmakers were compelled to amended the Belgian law to clarify that a full discharge is available even to debtors unable to make any payment to creditors. The law as originally formulated allowed judicial plans to impose only a partial discharge, requiring some payment from the debtor. Questions surfaced immediately about the plight of debtors with no ability to pay. The government insisted that the law allowed for a "quasi-total discharge," such as a "partial” discharge leaving only a nominal debt, like one franc. Many courts disagreed with the government, however, imposing a minimum required payout for debtors to be eligible for discharge. In April 2003, the Belgian constitutional court finally settled the issue by adopting the government's position. It held that extending relief only to debtors who could pay some portion of their debt violated the equality principle in the Belgian Constitution. ${ }^{135}$ The legislature swiftly responded with a reform proposal, which became the law of 15 December 2005. Among other modifications, the reform law brought the discharge provision into compliance with the constitutional court's ruling, providing explicitly for a total discharge even for debtors unable to pay anything to creditors. ${ }^{136}$

It might be both more honest and more meaningful to refer to these arrangements as “debt adjustment" plans, rather than "payment" plans, or better yet something like "rehabilitation" plans, to focus on their real purpose. Especially in places like Germany, where the overwhelming majority of plans produce no payment to creditors, yet debtors are required to

\footnotetext{
${ }^{131}$ See Kilborn, supra note 75, at 453.

${ }^{132}$ Faillissementswet art. 352(2) (version prior to 1 Jan. 2008). This provision, now in art. 354a, has been slightly broadened to allow for early discharge after one year if the court is convinced by a reasoned analysis from the trustee that "it is not anticipated that the debtor can fulfill his obligations in such a way that continuation of the debt adjustment is justified.” I doubt this reformulation will result in a noticeable increase in early case endings.

${ }^{133}$ See Jason Kilborn, The Hidden Life of Consumer Bankruptcy Reform: Danger Signs for the New U.S. Law From Unexpected Parallels in the Netherlands, 39 VAND. J. TRANSNAT’L L. 77, 106-07 (2006).

${ }^{134}$ See Kilborn, supra note 90, at 291-92.

135 See Kilborn, supra note 108, at 93-94.

136 See Gerechtelijk Wetboek/Code judiciaire art. 1675/13 bis.
} 
remain "in administration" for six full years, the purpose of the aptly called "good behavior period" $" 137$ is more about good behavior, and inculcating responsibility, than about payment.

Nevertheless, European legislators seem to reasonably disagree with INSOL's recommendation for an immediate and unconditional discharge for totally impoverished debtors, and that "there is no benefit extending insolvency procedures for a longer period" for such debtors. On the contrary, European policy seems rather consistently to recognize at least a pedagogical purpose to be served; that is, multi-year plans remind debtors and those around them that everyone must do their best to fulfill their obligations, whatever that "best" is, and budgetary guidance and supervision might be provided to debtors during the plan period to reinforce this goal. To one degree or another, this pedagogical purpose is moralistic, inculcating good payment morality by reminding debtors that they must sacrifice their own comfort and desires to offer something to their creditors, even if debtors "have nothing to offer but blood, toil, tears and sweat." "138 The Belgian government and parliament made this point clearly, noting that nopayment plans have a "symbolic character," with debtors demonstrating worthiness for discharge by subjecting themselves to the plan's constraints and furnishing an effort to pay their debts over several years. ${ }^{139}$ Moreover, it does make some theoretical economic sense to at least offer creditors what they might legitimately have expected when entering into credit arrangements. While lifelong indebtedness and social exclusion for debtors are not reasonable expectations, creditors might legitimately expect debtors to apply their full disposable payment capacity over a reasonable period of time to service their debts. The notion of "disposable payment capacity" and the appropriate length of the "reasonable period of time" are separate matters, discussed below, but the idea of requiring a plan of everyone has some undeniable, if controversial, merit. The key question for the future is pointed out in the iff report: is it worth the substantial administrative expense on the state to require protracted debt adjustment plans in every case in order to achieve these moral-educational goals?

One jurisdiction has finally responded in the negative. France's long accumulated experience has prompted it to move steadily and now decisively in the direction suggested by the iff report. The series of reforms in the past decade in the robust French overindebtedness system most vividly illustrates progression toward exempting large groups of debtors from payments and plans altogether, in large part to avoid a resource-intensive and unproductive administrative burden. Originally, the French law only invited creditors to offer their debtors a remission; it did not allow the courts to impose a discharge. Soon, a "revolving door" phenomenon became apparent, as debtors returned after the expiration of a previous ineffective restructuring plan to request more relief. After ten years of this, effective 1 February 1999, the French legislature armed the commissions with the additional tool of "extraordinary" measures; that is, global deferral of all debts for three years (in 2004, reduced to two years) followed by a partial or total discharge if the debtor remains "insolvent." When later surveys revealed that more than a quarter of all debtors had no ability to repay any of their debts, yet few debtors were receiving “extraordinary” discharge relief, the legislature took even more aggressive action.

\footnotetext{
${ }^{137}$ This is the German term for the repayment period, Wohlverhaltensperiode.

${ }^{138}$ See Wikipedia, “Blood, toil, tears, and sweat,” http://en.wikipedia.org/wiki/Blood,_toil,_tears,_and_sweat.

139 See Kilborn, supra note 108, at 88, 93.
} 
As of 25 February 2004, the commissions have been able to recommend that debtors whose financial situation is "irremediably compromised" be routed to a new procedure, called "personal recovery” (rétablissement personnel). A personal recovery procedure is very similar to a U.S. "Chapter 7" consumer bankruptcy proceeding, offering a full and immediate discharge, with no rehabilitation plan of any kind. ${ }^{140}$ As mentioned above, the French legislature recently moved to make even this process more efficient and less time-consuming for the courts. The original idea was that personal recovery cases would involve at least an inventory of the debtor's assets (and debts) and a potential liquidation of those assets. As anticipated, very few of these debtors had any assets worth liquidating, so effective 1 November 2010, the commissions can recommend a personal recovery procedure without liquidation of assets - effectively, an immediate and completely unconditional discharge. The percentage of administered cases routed through a personal recovery procedure has grown steadily from about $11.5 \%$ in 2004 to nearly $25 \%$ in 2009. In the first six months of 2010, the number of new personal recovery procedures has grown another $16 \%$ over the same period in $2009 .{ }^{141}$ Tens of thousands of debtors every year in France are receiving a discharge with no payment plan or observation period at all.

\section{Payment plans should not be overly extended}

The appropriate length of time to expect debtors to work largely for the benefit of their creditors has been a hotly debated topic, and the debate continues unabated even in countries with well-established systems. Moving away from lifelong indebtedness is already an extremely positive step, but countries that have made that move have struggled with the choice of a shorter period of indentured servitude. ${ }^{142}$ One thing is relatively clear: Huls's recommendation of "significant flexibility with respect to duration of the plan" has been roundly rejected. Even in the many systems that allow for some discretion in the length of plans, practice has quickly become standardized almost everywhere, usually settling on the upper end of the given range. ${ }^{143}$

The specific recommendations with respect to plan duration are divided and seem to struggle themselves to find an optimal plan duration. Huls and the iff report favor three or four years, while the INSOL report suggests that plans "should not be over-extended," but it seemingly accepts existing procedures with seven- or eight-year plans. Likewise, while the Best Project on Bankruptcy calls for “early discharge," holding up Finland’s five-year plan as a model, it also categorizes the German and Austrian requirement of seven years as "full implementation" of this recommendation. The Debt Amnesty Peer Review observers were impressed with the Dutch three-year period, and all agreed that a "reasonably short time," in any event less than seven years, would be best. The Council of Europe remains aloof on this point, directing only that countries adopt “reasonable” plan durations to protect debtors' human dignity.

\footnotetext{
140 See Kilborn, supra note 84, at 648-51, 655-60.

${ }^{141}$ See Banque de France, Statistiques mensuelles du surendettement, online at http://www.banquefrance.fr/fr/instit/protection_consommateur/statistiques_mensuelles_surendettement.htm.

${ }^{142}$ For discussions of the various thought processes that went into defining the various repayment periods, see Kilborn, supra note 82, at 172 (Denmark); Kilborn, supra note 75, at 450 \& n. 92 (Sweden); Kilborn, supra note 90, at 282-83 (Germany); Kilborn, supra note 108, at 86-88 (Belgium and Luxembourg); Kilborn, supra note 132, at 102-03 (the Netherlands).

143 This practice was confirmed in reform legislation in Sweden, where after 1 January 2007, the system administrator generally may no longer craft plans exceeding the standard 5-year duration. See Kilborn, supra note 75, at 450 \& n. 94. Note that the Netherlands represent an exception to the norm of gravitating toward the top of the range, as the standard Dutch plan length is the lower end of the allowed range of 3 to 5 years.
} 
With this hodge-podge of divergent recommendations, it would be difficult to find fault with virtually any of the existing procedures, with the exception of Ireland's twelve-year waiting period for a discharge. One can observe, however, two distinct trends: a gradual movement toward reducing the length of the repayment period, and a gravitation toward five years as the median plan duration.

On the first point, France, Germany, and Latvia have reduced the length of the payment period, and reform proposals are pending in Germany and Sweden to reduce the period further. The maximum repayment period for court-imposed plans in France has first risen and now most recently begun to fall. Originally, court-imposed plans could not exceed five years, but this limit was raised to eight years in 1999, and then to ten years in 2003 to conform to the reduced limit for out-of-court plans. ${ }^{144}$ Most recently, effective 1 November 2010, the maximum has been pulled back to eight years, for both out-of-court and court-imposed plans. This is still the longest allowed period for court-imposed plans in Europe, but it is better than ten years, and the majority of court-imposed plans do not exceed five years. ${ }^{145}$ Also effective 1 November 2010, a reform law adopted by a vote of 90 to zero by the Latvian Saeima (parliament) reduced the payment period of that relatively new law (effective only since 1 January 2008) from seven years to a maximum of three-and-a-half years. ${ }^{146}$ Years earlier, in 2001, the German Bundestag had also reduced the original seven-year "good behavior period" to six years and tied the beginning of the period to the opening, rather than the conclusion, of the simplified insolvency proceeding stage. Sustained calls continued for further reduction of this still extraordinarily long six-year period. On 17 March 2010, the Federal Minister of Justice delivered a speech in which she promised a forthcoming reform proposal to halve the six-year period to three years. A similar proposal from the Swedish government to reduce Sweden's five-year repayment period to three years is under discussion in the Swedish legislature. ${ }^{147}$ If these latest initiatives are successful, Germany and Sweden would join the Netherlands, Slovakia, Latvia, England \& Wales, and Greece in adopting the low-end recommendation of Huls and the iff report with a three- to four-year plan period.

Elsewhere in Europe, five years remains the most common period, but the newest laws (in bold in the table below) have often chosen shorter periods. The following table catalogues the non-consensual (that is, imposed on creditors by a court or administrative body) debt adjustment periods in Europe, arranged from longest to shortest. This table assumes no more reforms are adopted after August 2010, and that plans offer an average payment to creditors of no more than $15 \%$ of total debt ${ }^{148}$ (that is, ignoring the rare possibility of shorter plan periods for higher dividends or, in England \& Wales, an IVA generally spanning 5 years).

\footnotetext{
144 See Kilborn, supra note 84, at 647 n. 208.

145 See Banque de France, Enquête Typologique 2007 Sur le Surendettement 26 \& tbl. 25 (Sept. 2008), online at http://www.banque-france.fr/fr/instit/telechar/services/enquete typo2007 surendettement.pdf.

${ }^{146}$ See Aaron Eglitis, Latvia's Personal Bankruptcy Law Won't Impact Nordic Lenders, Nordea Says, Bloomberg.com (27 July 2010), http://www.bloomberg.com/news/2010-07-27/latvia-s-personal-bankruptcy-lawwon-t-impact-nordic-lenders-nordea-says.html.

${ }^{147}$ See Vägen tillbaka för överskuldsatta, SOU 2008:82, at 27-28, online at http://www.regeringen.se/content/1/c6/11/20/95/fe91859c.pdf; Interpellation 2009/10:186 (15 Jan. 2010), online at http://www.riksdagen.se/webbnav/index.aspx?nid=63\&dok_id=GX10186.

${ }^{148}$ Studies have suggested that $15 \%$ is an average recovery in these cases. See iff report, supra note 32, at 167.
} 
Table 1. Ordinary, nonconsensual debt adjustment plan periods in 18 EU Member States and Norway

\begin{tabular}{|l|l|}
\hline France & up to 8 years \\
\hline Austria & 7 years (possible extension to 10 to reach $10 \%$ min. dividend) \\
\hline Luxembourg & up to 7 years \\
\hline Germany & 6 years (from beginning of simplified insolvency proceedings) \\
\hline Norway & 5 years (though commonly up to 7 to 10 years) \\
\hline Denmark & 5 years (possible extension to regain missed payments) \\
\hline Sweden & 5 years (possible extension up to 7 to regain missed payments) \\
\hline Finland & 5 years (possible up to 7 for guarantors, 10 for mortgages) \\
\hline Czech Republic & 5 years (min. 30\% dividend, unless hardship) \\
\hline Estonia & 5 years \\
\hline Portugal & 5 years \\
\hline Belgium & 3 -5 years (in non-capital discharge plan, no min., possible extension for mortgage) \\
\hline Slovenia & $2-5$ years (from beginning of proceedings) \\
\hline Poland & up to 5 years \\
\hline Greece & 4 years \\
\hline Latvia & 3.5 years (down from 7 in original 1/1/2008 law) \\
\hline Slovakia & 3 years \\
\hline Netherlands & 3 years (up to 5 if more than minimum income provided, but $>3$ extremely rare) \\
\hline UK (England \& Wales) & up to 3 years (of income payments, but discharge after 1 year) \\
\hline
\end{tabular}

If the Swedish and German reforms are successful in reducing those countries' plan periods to three years, the formerly clear preference for five years will be in serious question. Time will tell how practice develops in Poland and Slovenia, both of which allow for plans shorter than five years, and if they follow the trend toward shorter plans, Huls, the iff report, and the Debt Amnesty Peer Review's recommendations may yet gain the upper hand. In any event, it seems fair to observe that the clear preponderance of practice has already adopted the general recommendation of early discharge, though in terms of numbers of heads, the vast majority of debtors in Europe pass through the exceptionally extended periods in France and Germany.

\section{Payment amount should reasonably support human dignity}

Along with the proper length of time to leave petitioners in debt purgatory, the most crucial question in these systems is the appropriate financial demands to make of debtors during the debt adjustment period. As the INSOL report observes, these procedures are not necessarily designed just to maximize creditor returns, so the most central question is not what creditors must be paid, but what portion of a debtor's income will be reserved for supporting the debtor's family's reasonable needs and, as the Council of Europe emphasized, having due regard for their human dignity. The recommendations are vague on this point, but they all agree that debtors should be left with sufficient income to meet their basic needs and necessary living expenses, especially housing.

After some early difficulties with leaving debtors far less financial support than a reasonable standard of living would require, the existing systems seem to be heeding the recommendation for reasonable payment demands and preserving debtors' human dignity. Many jurisdictions have also faced problems with the Council of Europe's call for uniformity, though recent reforms have begun to tackle this problem, as well. The most recent laws, however, seem

\footnotetext{
${ }^{149}$ See Graver, supra note 118, at 168-69 (noting that, in the early years of the Norwegian system, courts deviated upwards more often than not in some regions).
} 
to revert to an unbridled discretionary approach, which portends trouble to come in these jurisdictions in light of earlier negative experience with similar procedures elsewhere.

Existing debt adjustment laws generally take one of three different approaches to calculating the amount of the debtor's income to be budgeted for family support, with any excess to be distributed to creditors over the plan duration. Most laws today co-opt the general civil execution law that limits the amount of the debtor's income that can be seized (garnished) by general creditors. Whatever income would be protected in ordinary enforcement proceedings is reserved for the debtor's family in overindebtedness cases, as well. Garnishment laws in these jurisdictions often include an absolute floor, below which all income is reserved for the debtor. Instead of allowing creditors to leave the debtor on this subsistence income for life, the overindebtedness laws set a finite boundary on the number of years that this income can be garnished. This approach is taken today in France, Denmark, Sweden, Austria, Germany, Estonia, the Czech Republic, Belgium, and it seems to be the case also in Latvia. ${ }^{150}$

Earlier, the laws in France, Denmark, and Sweden had left the budgetary reserve to a discretionary determination of "reasonableness" by system administrators. In light of miserly allowances and undesirable regional non-uniformity, however, lawmakers imposed clearer guidelines later. In France, some commissions in the early years exercised their discretion to leave debtors with woefully insufficient household budgets (as little as $€ 100$ per month per person), and budgetary practices varied considerably among the different commissions. After years of criticism of these unconstructive practices, the legislature abandoned the discretionary approach and adopted the national general garnishment restriction as the starting point to be left to debtors, implicitly inviting the social worker on each commission to recommend a higher budget. $^{151}$ The most recent reform law, effective 1 November 2010, attempts to increase transparency (and likely uniformity) by directing each commission to adopt and make public a governing guideline, which presumably will include operating standards for budgetary determinations, and to make a report annually on their practices. ${ }^{152}$

In Sweden, though the law originally suggested that the general garnishment limitation should be simply "guiding," the regional system administrators have almost never strayed from the guide, other than to "top up" the allowance with an extra "buffer" for unanticipated expenses (averaging generally around $€ 30$ per month). ${ }^{153}$ Before unification of the regional administrative bodies in 2006, the existence and amount of the "buffer" varied considerably from region to region, but greater uniformity is expected after the administrative consolidation.

Wide disparities in judicial appreciation of the original Danish statutory standard of "modest” budgetary allocations also posed serious problems, so much so that some counselors advised debtors living in especially miserly districts to move to nearby areas where relief was

\footnotetext{
${ }^{150}$ I have been unable to determine exactly how the Latvian law makes provision for payments from the debtor's future income, though it clearly seems to envision future income payments, see s. 155(1)(5)-(8), and it does protect personal property not subject to seizure under general civil enforcement law, see s. 176. It appears that the income payments aspect of the case is left to judicial discretion, but likely subject to general civil enforcement restrictions. See Latvian Insolvency Act s. 157(1)(3), 158(7), 174(1), 175.

${ }^{151}$ Code de la consommation art. L.331-2; Kilborn, supra note 84, at 630-32, 642-44, .

${ }_{152}^{152}$ Code de la consommation arts. L.331-1 (final clause), L331-12 (new).

${ }^{153}$ See Kilborn, supra note 75, at 450-53.
} 
available on more generous terms. In 2005, the Danish legislature adopted the first major reform of its debt adjustment law primarily to address this problem. It charged the Justice Ministry with establishing uniform basic budgetary allowances for both general garnishment and debt adjustment cases, though still subject to flexible guidelines for variable expenses like housing and child care. A positive side-effect of this reform was to offer more generous budgets to most debtors. The basic budget allowance adopted by the Justice Ministry was nearly $20 \%$ higher than the upper range then applied in most debt adjustment cases, and more types of income were excluded from seizure (i.e., reserved to debtors), such as transfer payments for children. ${ }^{154}$

Like in Denmark, legislators in Germany reformed the general garnishment restriction to increase the budgets for most debtors. After implementation of the new insolvency law in 1999, complaints about the burden of long payment periods on this tight budget prompted the Bundestag to revisit the garnishment reserve generally. At the same time when it reduced the "good behavior period" from seven to six years, the Bundestag significantly increased the amount of income reserved for debtors and their families. Beginning 1 January 2002, the minimum statutory wage exemption for single debtors and childless couples, and the maximum exempt amount for all debtors, rose nearly 50\%, and the levels were finally subjected to biannual indexing to keep pace with inflation ${ }^{155}$ Another unique innovation appears in both the German and Estonian laws. To encourage debtors to keep progressing through the five- or sixyear debt adjustment period, these laws offer debtors a "motivation rebate" at the end of each year (in Estonia) or the fourth and fifth years (in Germany). A stated percentage (between 10\% and $25 \%$ !) of the income transferred by the debtor to the trustee during the preceding year is refunded to the debtor, not distributed to creditors. ${ }^{156}$

In Belgium, the limitation on financial demands imposed on debtors is at first stated simply and vaguely in a way that seems to incorporate the Council of Europe's human rights directive: debtors and their families must be guaranteed the ability "to lead a life in conformity with human dignity." "157 Indeed, the Belgian law had to proceed from this baseline, as the Belgian Constitution establishes this basic right in exactly these words as a generally applicable proposition. In the original law, no clear mention was made of using the general garnishment exemptions to form a "human dignity" baseline, but the reform law of 15 December 2005 finally made this clear. The law still allows debt mediators and judges to reach into the exempt reservoir "by specially motivated decision," but as in France, the absolute limit that must be left to the debtor is the minimum "revenue of social integration."

This "minimum income" is the focus of the second major approach to calculating the debtor's reserved budget. It references only the minimum income preserved by the general social insurance program, without regard to the debtor's actual income or garnishment restrictions. This can be quite generous, as in the exceptional case of Norway, where debtors are allowed to keep $85 \%$ of the national social insurance allowance, plus extra housing costs. ${ }^{158}$ More often, very little income is protected for debtors, though the usual result is that this

\footnotetext{
154 See Kilborn, supra note 82, at 160 n. 22, 172, 174, 176-78.

155 See Kilborn, supra note 90, at 267-68, 285-86.

${ }^{156}$ Insolvenzordnung s. 292(1); Estonian Bankruptcy Act s. 173(4).

${ }^{157}$ Gerechtelijk Wetboek/Code judiciaire arts. 1675/3, 1675/12 § 4, 1675/13 § 5.

158 See Graver, supra note 118, at 168; European Commission, Common Definition, supra note 52, at 89 (noting that Norway is famous for its high reserve of $85 \%$ of the minimum pension, much higher than social assistance levels).
} 
approach differs little from the one oriented on the general garnishment limit, since many debtors' incomes lie at or below the floor for income absolutely shielded from garnishment, which is also often the same as the floor for social security. This approach is taken today in the Netherlands and Slovenia, ${ }^{159}$ though the Dutch approach is somewhat more complex than the face of the law would suggest.

Unlike other European overindebtedness laws, the Dutch “Wsnp” establishes the debtor's "exempt" budget not as a percentage of the debtor's total income, but as a percentage of the general welfare assistance level for various types of debtors. The law seems to require debtors to turn over all income in excess of $90 \%$ of the basic social assistance minimum income, subject to a series of adjustments based on certain of the debtor's household expenses. The more important section, though, is the one that follows, which affords the judge discretion to increase the debtor's budget. ${ }^{160}$ A national working group of Dutch bankruptcy judges (Recofa) in late 2000 established a uniform basis for calculating the so-called "amount to be left free" for debtors (vrij te laten bedrag, or vtlb), which reserves significantly more baseline income to debtors than the statutory $90 \%$ of the social assistance minimum income and more carefully regulates extra allowances for expenses like housing, childcare, and transportation. The Recofa calculation guide has since been adopted as the standard by nearly all courts, and increasingly by officials in normal judicial execution proceedings, as well. ${ }^{161}$ The Debt Amnesty Peer Review observers speculated that the Wsnp's very short three-year debt adjustment period might be counterbalanced by their perception that "debtors are allowed a significantly higher retained income" in other countries, but they may well not have understood that the "law in books" differs here in a fundamental way from the "law in action." The Dutch approach represents an exceptionally impressive combination of a reasonably short repayment period and reasonably sensitive and sufficient debtor budgets.

Finally, though this problematic approach was abandoned by France and Denmark, as discussed above, some countries continue to leave debtors' budgetary reserves to the discretion of a judge or other system administrator, generally guided only by a vague directive to provide for debtors' "reasonable needs" or "human dignity. " For example, in Luxembourg, the only provision constraining judicial discretion in determining debtor budgets is drawn from the Belgian law: courts must simply guarantee debtors and their families "a life in conformity with human dignity."162 Lawmakers intentionally left this vague standard open for discretionary judicial interpretation. ${ }^{163}$ A broad discretionary approach was also adopted in the new Greek law, ${ }^{164}$ and it appears to be the approach taken in Slovakia, ${ }^{165}$ and Poland. ${ }^{166}$ These systems risk

\footnotetext{
159 See Slovenian Insolvency Act s. 389.

${ }^{160}$ Faillissementswet art. 295(2)-(3).

161 See Kilborn, supra note 132, at 98-101.

162 See Law of 8 Dec. 2000, art. 1.

${ }^{163}$ See Kilborn, supra note 108, at 88-89 \& n.106 (noting that legislators in Luxembourg decided simply that this approach is "preferable" to identifying a minimum figure, such as the "minimum guaranteed revenue" established by law in Luxembourg as in other European countries).

${ }^{164}$ Art. 8(2) (directing the judge to balance the debtor's income with the debtor's and his family’s living needs).

165 The Slovak law refers simply to "the amount specified by the court," which the debtor must cede to the trustee, limited to "up to 70\% of his total net income.” Slovak Insolvency Act s. 168(A). I could find no more detailed explanation of what these phrases mean or how they have been applied in the limited experience under the new law.

${ }^{166}$ The new Polish law (s. 491[7]) is particularly vague, providing no guidance to the judge in determining when and how much the debtor must pay creditors and how much of the debtor's obligations will be discharged.
} 
falling into the same traps from which France and Denmark escaped after years of trial and error. One hopes that the legislatures in these states will be as vigilant as those in France and Denmark and will follow the Council of Europe's recommendation to impose clearer guidelines and preserve uniform minimum standards if courts fail to exercise their discretion in a way that meets these important goals.

\section{Allow for modification for unforeseen weakness, improvements}

Finally, even if debt adjustment plans are reasonable at first, much can change over the long rehabilitation periods called for by many of these laws. Huls and the iff report recommend that laws include some facility for modifying a plan for changed circumstances, whether the debtor's circumstances improve or deteriorate. The other recommendations do not mention modification, perhaps because this has not proven to be a major problem in most systems, or it has been successfully overcome where it has posed challenges.

The most sensible way to approach this problem is to make plans self-modifying; that is, the debtor's payment requirements change with the debtor's income automatically, without the need for modification requests for positive or negative changes in circumstances. In Germany, Austria, Estonia, the Czech Republic, and Slovenia, the debtor's payment obligation is not settled in advance; rather, the debtor either automatically assigns (Germany, Austria) or makes payments monthly (Estonia, Czech Republic, Slovenia) of any amounts not protected from garnishment. This approach avoids the problem of modification entirely, with the only drawback that it is not overly flexible in taking into account differing needs for different debtors and families.

In areas that establish payment obligations in anticipation of projected income, taking into account differing debtors' needs in allocating budgets, modification is usually specifically provided for (e.g., Denmark, Sweden, Belgium, Luxembourg, Latvia, Poland, Greece). ${ }^{167}$ The Danish rules on modification of ongoing plans are unique, and early problems prompted a reform in 2005. Post-confirmation modification of the plan is allowed under the Danish law, but only in the debtor's "most exceptional interest," 168 so modifications for improvements in the debtor's financial situation are not allowed. The original law allowed for changes to aid the debtor to make the payments called for in the plan, but only by lengthening the repayment period (beyond five years) to allow time for the debtor to catch up on arrears-a problem that turned out to be much more common than expected. Given this limitation, debtors often simply dismissed their cases and refiled anew, in which case a new plan would be crafted based on the debtors' newly

\footnotetext{
${ }^{167}$ Slovakia seems to be an exception, making no obvious mention of plan modification, though it may be that the payment amount in the Slovak system also changes in accordance with the debtor's actual income subject to seizure, see supra note 165 . The Dutch law also does not seem to contain a general modification provision, other than one allowing for change in the duration of the plan. Faillissementswet art. 349a(2)-(3). I believe this provision is used much as in Scandinavia, to lengthen the plan to allow debtors to catch up on arrears if need be, though ultimately, the uniquely short three-year standard plan duration likely renders this question largely moot in the Netherlands. Finally, in France, the overindebtedness system has long observed a "revolving door" of debtors' refiling cases after having been unable to comply with an earlier adjustment plan. French legislators seem to have chosen to respond to this problem not by allowing for modification of plans, but by gradually ratcheting up available forms of relief and routing more debtors to procedures not involving extended payment plans at all (i.e., extraordinary recommendations and personal recovery procedures).

${ }^{168}$ Konkurslov § 228 (“ganske særlige hensyn”).
} 
depressed financial circumstances. A 2005 reform law addressed this problem by allowing for modification of any aspect of the plan, including reduction of the required payout to as little as zero. $^{169}$

\section{F. Other recommendations}

The preceding analysis concentrated on the most fundamental shared recommendations. This final section concludes with three more that are worthy of note, even though they appear in only one or two of the sources. These other recommendations have been incorporated into some national laws, and they raise issues that merit strong consideration in future policy discussions.

\section{Good faith for creditors}

Though the notion of creditors' good faith and their responsibility for debtors' financial predicament appears often in the legislative histories of debt adjustment laws, very few laws contain any specific provision on this point. The Debt Amnesty Peer Review observers, however, emphasized their view that, if debtors' good faith is to be so heavily scrutinized (as it is in the Dutch system), then creditors' good faith should be examined as well. As noted above, only the Dutch and French laws specifically require "good faith" of debtors petitioning for relief, and the peer reviewers might have looked to the French law for an example-at least theoretical — of what they expected here. The main thrust of the original French "Loi Neiertz" was to require more responsibility from creditors when making decisions on extending credit. If lenders extend credit to consumers who ultimately find themselves in the overindebtedness system, the law directs the commission to "take into account the knowledge of the debtor's debt situation that each creditor might have had at the time of execution of the different contracts," and to "verify that the contract was entered into with the seriousness imposed by standards of professional practice." 170 While not explicitly demanding a "good faith" inquiry of creditors, the French law encourages the commissions to sanction lenders who make foolish or unfounded loans, primarily those who extend credit to already overextended debtors. ${ }^{171}$ This provision does not seem to be applied nearly as aggressively as the good faith requirement for debtors, but it is a solid foundation on which the French and Dutch overindebtedness systems might build toward a more evenly balanced appraisal of debtors' and creditors' good faith, consistent with the Debt Amnesty Peer Review’s recommendation.

\section{Protection for guarantors}

The iff report raises to the level of a principle the notion of protecting personal sureties from the effects of discharge of their principal obligor's guaranteed debts. At that time, no state specifically provided for "collateral" effect of a discharge to benefit guarantors of the discharged debt $^{172}$ — most likely because guarantees are used precisely as security for the insolvency of the

\footnotetext{
${ }^{169}$ Konkurslov ss 228-229; see also Kilborn, supra note 82, at 179-80.

${ }^{170}$ Code de la consommation art. L.331-7 (2004).

${ }^{171}$ See Kilborn, supra note 84, at 669-70.

${ }^{172}$ A unique provision in the Finnish law offers mild protections for guarantors (and third-party home mortgagors) of debts on which the principal obligor has been discharged, but only by reducing interest obligations on the guaranteed obligation and subjecting the creditor to a five-year plan that offers payment in full. Johanna Niemi, The Finnish Act on the Adjustment of the Debts of a Private Individual 9 (2010 manuscript on file with author).
} 
principal borrower. The plight of co-obligors generally was raised in the discussions leading up to the German law, but protections for guarantors and other co-obligors was intentionally excluded, since these people could simply apply for relief under the overindebtedness law themselves in case of need. But in December 2005, Belgium adopted what seems to be the first provision specifically extending protection to guarantors. Only natural persons and gratuitous sureties are covered, but such people are allowed to petition for a discharge of a suretyship obligation implicated in a pending debt adjustment case for the principal obligor if the surety's resulting obligation is "disproportionate to his revenue and patrimony."173 This unique provision seems unlikely to be adopted elsewhere, but it is noteworthy that at least one jurisdiction seems recently to have taken the iff report's unique recommendation to heart.

\section{Cross-border recognition of discharge}

One final substantial challenge for the growing corpus of overindebtedness laws lies in the larger domain of private international law. If a discharge under one state's debt adjustment law either does not affect creditors and property in other states, or is not recognized at all in other states, ${ }^{174}$ debtors' freedom of movement (and the free migration of labor) will be constrained. It may be that this problem will be relatively isolated if the great bulk of debtors resorting to overindebtedness relief systems will have creditors and assets in one state or will remain in the territory of that state after their discharge. It seems more likely, however, that cross-border credit arrangements will be commonplace for many or even most European debtors, and that many debtors will seek work in other states after their incentive to engage in productive activity has been renewed by a discharge of their debts. If the fruits of these debtors' labor in other states will be encumbered by old debts not subject to an earlier discharge in their original home states, the very raison d'être of these debt adjustment laws will be seriously undermined.

The INSOL report, the iff report, and the Expert Report that preceded the Council of Europe's recommendations ${ }^{175}$ all point out this potential problem and recommend broad crossborder recognition of discharge. They also all observe that the EC Insolvency Regulation ${ }^{176}$ is a solid foundation for a solution, but it is oddly incomplete. First, it does not apply at all to discharges obtained in Denmark and Norway (or to inbound debtors with discharges from other, non-Scandinavian ${ }^{177}$ states), because these two are not EU Member States. Second, the list of proceedings in Annex A, the results of which are automatically entitled to recognition in other Member States, does not include mention of the overindebtedness proceedings in several states. This is likely not a problem for those states where debt adjustment is just one aspect of the general insolvency procedure (e.g., Germany, Austria, Estonia, Poland, ${ }^{178}$ Portugal, Slovenia,

\footnotetext{
${ }^{173}$ Gerechtelijk Wetboek/Code judiciaire art. 1675/16 bis.

${ }^{174}$ See, e.g., Apeldoorn, supra note 127, at 64 (describing one such situation from 1998, where Dutch courts refused to acknowledge a discharge under French law).

175 See Niemi-Kiesiläinen \& Henrikson, supra note 54, at 38-41.

${ }^{176}$ Council Regulation (EC) 1346/2000 of 29 May 2000 on Insolvency Proceedings [2000] OJ L160, p. 1.

177 Scandinavian international private law in this area is governed by the Nordic Bankruptcy Convention of 1933, and since the debt adjustment laws in the region are so similar, one could expect comity for discharges obtained in neighboring Scandinavian states in any event.

${ }^{178}$ It seems that the special provisions for persons not engaged in business would be included within the scope of the specific Upadłość procedures mentioned by Poland in Annex A, but this is not entirely clear.
} 
Slovakia ${ }^{179}$ ), or who have mentioned their specific debt adjustment procedures in Annex A to the Regulation (e.g., Belgium, the Netherlands, the Czech Republic, Latvia). In France, Finland, Luxembourg, and Sweden, on the other hand, where debt adjustment is the subject of a separate, non-insolvency law, these procedures are not mentioned in Annex A to the Regulation, and so the cross-border portability of a discharge in these states is at least unclear, if not doubtful.

These states, along with Greece, whose new law is also a distinct and independent procedure, might at least be encouraged to list their debt adjustment procedures in Annex A. Both liquidation and reorganization proceedings are mentioned by most states in Annex A, so there appears to be no impediment to France, Finland, Luxembourg, Sweden, and now Greece simply adding their specific consumer rehabilitation procedures to the list. At the end of the day, with a majority of Member States having adopted debt adjustment laws offering a discharge, the "minimally harmonized" process and result of these laws does not vary so greatly that any state should be allowed to object to the cross-border operation of a discharge under any other Member State's law (or under the similar laws in Denmark and Norway). ${ }^{180}$

\section{Conclusion}

I was pleasantly surprised and impressed to see the degree to which national laws had tracked the expert consensus on best practices. There may well be no causal connection here, but it is at least satisfying to see these greats minds thinking alike, more and more so through an accelerating pace of reforms. The one area where legislators in a few areas lag behind their neighbors and the experts is, unfortunately, one of the most key aspect of these systems' success - getting people through the gateway to relief. By allowing cost and stringent eligibility requirements to remain barriers to access, a few of these laws are hindering the achievement of the most essential goals of overindebtedness relief. No one really wins when honest but unfortunate debtors are prevented from escaping from "undue demands and harassment by their creditors" as the Cork Commission observed nearly three decades ago. The losses to society from the unchecked continuation of "unproductive [and] ineffective debt-collection" are not insignificant, and any benefits to such an approach are illusory. The time has come for European policymakers to realize that the old stand-by of pacta sunt servanda has earned its retirement. The importance of fulfilling one's obligations should go without saying, as it clearly does still today, but modern society calls for a more nuanced appreciation of how the casualties of that slogan can and should be treated to ensure an optimal level of financial health for Europe.

\footnotetext{
${ }^{179}$ Slovakia has a distinct discharge procedure (oddlženie) that applies to natural persons after the general bankruptcy procedure, like the Czech Republic (oddluženi), but unlike the Czech Republic, Slovakia does not seem to have chosen to list the specific separate procedure in Annex A. The result is probably like that in Germany and the other states in this list, but greater clarity on this point would be desirable.

180 The more pressing immediate problem is "bankruptcy tourism," with higher-income debtors seeking relief under the more liberal procedures in, e.g., the UK, after strategically changing their "centre of main interests" from countries with more arduous procedures, e.g., Germany. See, e.g., Adrian Walters \& Anton Smith, 'Bankruptcy Tourism' under the EC Regulation on Insolvency Proceedings: A View from England and Wales, online at http://ssrn.com/abstract=1630890.
} 